\title{
LOS TESTAMENTOS COMO FUENTE PARA LA HISTORIA SOCIAL DE LA NOBLEZA. UN EJEMPLO METODOLÓGICO: TRES MANDAS DE LOS VALLADARES DEL SIGLO XV
}

\author{
Pablo S. Otero Piñeyro Maseda* \\ Instituto de Estudios Gallegos "Padre Sarmiento" \\ CSIC-Xunta de Galicia \\ Miguel García-FernándeZ** \\ Universidad de Santiago de Compostela
}

\begin{abstract}
* El presente texto se enmarca en el proyecto de investigación Linaje, parentela y poder: la pirámide nobiliaria gallega (siglos XIII al XV) (I) (MICIIN, Plan Nacional de I+D+I. Ref. HAR201018378), del que es investigador principal el Dr. Eduardo Pardo de Guevara y Valdés. La participación de este coautor, por otra parte, se integra en el "Programa Nacional de Contratación e Incorporación de Recursos Humanos de Investigación", en el marco del "Plan Nacional de Investigación Científica, Desarrollo e Innovación Tecnológica 2008-2011” del MINECO, Subprograma "Juan de la Cierva" (convocatoria 2011), cofinanciado por el Fondo Social Europeo.

** El presente texto se ha realizado en el marco de la elaboración de la tesis doctoral La posición de las mujeres en la sociedad medieval. Un análisis de la práctica testamentaria en la Galicia de los siglos XII al XV, que desarrolla este coautor al amparo de una beca del Programa de Formación del Profesorado Universitario (FPU) del Ministerio de Educación, Cultura y Deporte, bajo la dirección del Dr. Ermelindo Portela Silva en el Grupo de Investigación GI-2108 "Historia social de Galicia en la Edad Media".
\end{abstract}




\section{LOS TESTAMENTOS COMO FUENTE PARA \\ LA HISTORIA SOCIAL DE LA NOBLEZA. \\ UN EJEMPLO METODOLÓGICO: TRES MANDAS \\ DE LOS VALLADARES DEL SIGLO XV}

\section{RESUMEN}

La identificación y estudio de los linajes que conformaron la pirámide nobiliaria gallega en la Baja Edad Media deben fundamentarse en un cuidadoso análisis de las fuentes, entre las que destacan por su especial caudal informativo los testamentos. El objetivo de estas páginas es ofrecer unas primeras reflexiones sobre esta tipología documental: examinar algunas tendencias y anotar cuestiones metodológicas para el mejor aprovechamiento de sus posibilidades en el contexto de la historia social de la nobleza. El estudio se completa, o ilustra, con la edición y comentario de los testamentos de tres personajes de la estirpe de los Valladares, todos del final de la Edad Media.

PAlabras Clave: Historia social de la nobleza, edición de fuentes documentales, Baja Edad Media, Galicia, testamentos, linaje de los Valladares.

\section{OS TESTAMENTOS COMO FONTE PARA A HISTORIA SOCIAL DA NOBREZA. UN EXEMPLO METODOLÓXICO: TRES MANDAS DOS VALLADARES DO SÉCULO XV}

\section{RESUMO}

A identificación e estudo das liñaxes que conformaron a pirámide nobiliaria galega na Baixa Idade Media deben fundamentarse nunha coidadosa análise das fontes, entre as que destacan polo seu especial caudal informativo os testamentos. O obxectivo destas páxinas é ofrecer unhas primeiras reflexións sobre esta tipoloxía documental: examinar algunhas tendencias e anotar cuestións metodolóxicas para o mellor aproveitamento das súas posibilidades no contexto da historia social da nobreza. O estudo complétase, ou ilústrase, coa edición e comentario dos testamentos de tres personaxes da estirpe dos valladares, todos do final da Idade Media.

Palabras Clave: Historia social da nobreza, edición de fontes documentais, Baixa Idade Media, Galicia, testamentos, linaxe dos Valladares.

\section{LAST WILLS AND TESTAMENTS AS A SOURCE FOR THE STUDY OF THE SOCIAL HISTORY OF THE NOBILITY. A METHODOLOGICAL CASE: THREE $15^{\mathrm{TH}}$ CENTURY LAST WILLS AND TESTAMENTS FROM THE VALLADARES LINEAGE}

\footnotetext{
Abstract

The identification and study of the lineages which made up the galician nobility pyramid in the Late Middle Ages must be based on a meticulous analysis of the sources, amoung which the most noteworthy are wills of testament due to there rich quantity of information. The objective of this work is to offer some preliminary ideas regarding this type of document. By examining diferent tendencies and describing methodologies, it is possible to make the best use of the information held within these documents in order to improve the study of the social history of the nobility. This work includes the publication and commentary of the wills of testament of three members of the Valladares lineage from the Late Middle Ages.

KEY wORDS: Social history of the nobility, publication of documentary sources, Late Middle Ages, Galicia, last wills of testaments, Valladares lineage
} 
Recibido/Received: 01/07/2013

Aceptado/Accepted: 26/08/2013

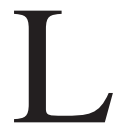

a identificación social y geográfica de los linajes que conformaron la pirámide nobiliaria gallega a partir del siglo XIII, empleando la reconstrucción de sus tablas de filiaciones y parentescos y los análisis prosopográficos correspondientes, constituye una sólida base para profundizar debidamente en el conocimiento de la nobleza medieval en el contexto de los estudios referidos a la sociedad en general, dado su extraordinario protagonismo y el poderoso influjo de sus ideales y normas de comportamiento ${ }^{1}$. Pero como en cualquier discurso histórico, las bases heurísticas sobre las que debe construirse el conocimiento de los linajes gallegos, sus redes parentales y los grupos de poder deben conformar un repertorio documental amplio —manuscritos, inscripciones epigráficas y emblemas heráldicos - debidamente estructurado y sólido en lo metodológico. En este punto, las mandas testamentarias representan uno de los tipos documentales privilegiados por su caudal informativo, y deben ser descritos, analizados y contextualizados en ediciones diplomáticas cuidadas y rigurosas, prestando especial atención a su propia tradición documental.

Una somera revisión de los estudios realizados acerca de la nobleza medieval gallega a partir del siglo XII ${ }^{2}$ — momento que coincide con el "resurgimiento" de la práctica testamentaria propiamente dicha ${ }^{3}$ - , permite observar el proceso

\footnotetext{
1 Eduardo PaRdo de Guevara y VAldés, De linajes, parentelas y grupos de poder. Aportaciones a la historia social de la nobleza bajomedieval gallega, Madrid, Fundación Cultural de la Nobleza Española; CSIC, 2012, pág. 15.

2 Véanse, a modo de ejemplo, los diversos trabajos dedicados al tema por José García Oro, caso de La nobleza gallega en la Baja Edad Media. Las casas nobles y sus relaciones estamentales, Santiago de Compostela, Bibliófilos Gallegos, 1981 (Biblioteca de Galicia, 20); los de Eduardo Pardo de Guevara y Valdés, entre los que destacan Los señores de Galicia. Tenentes y condes de Lemos en la Edad Media, A Coruña, Fundación Pedro Barrié de la Maza, 2000, 2 vols. o algunos de los contenidos en De linajes, parentelas y grupos de poder...; así como los de Ermelindo PoRtela Silva y María del Carmen Pallares Méndez recogidos en De Galicia en la Edad Media. Sociedad, espacio y poder, Santiago de Compostela, Xunta de Galicia, 1993 o "Los mozos nobles: grandes hombres, si fueran hijos solos", Revista d'Història Medieval, 5 (1995), págs. 55-74.

3 Sobre los orígenes y la evolución del testamento medieval continúa siendo referencia inexcusable el trabajo de Alfonso García-Gallo, "Del testamento romano al medieval. Las líneas de su evolución en España", Anuario de Historia del Derecho Español, XLVII (1977), págs. 425-497.
} 
de difusión de los testamentos durante los siglos XIV y XV y su uso, más o menos generalizado, como fuente para el estudio de los grupos de poder, sean o no hidalgos ${ }^{4}$. Por esta razón, resulta muy oportuno reflexionar sobre algunas de las posibilidades informativas que ofrecen estos documentos, y al mismo tiempo, demostrar las limitaciones o prevenciones en su uso para el estudio de la sociedad noble; de ahí la edición, a modo ilustrativo, de tres mandas testamentarias otorgadas por miembros del linaje de los Valladares al final de la Edad Media, susceptibles de análisis si se atiende a la importancia de su tradición documental.

\section{TENDENCIAS, POSIBILIDADES DE ESTUDIO Y COMENTARIOS METODOLÓGICOS}

El valor de los testamentos como fuente para la historia social y de las mentalidades ha sido destacado por diversos historiadores ${ }^{5}$. En el caso gallego, conta-

\footnotetext{
${ }^{4}$ Es ciertamente notable el protagonismo que adquieren los testamentos de las aristocracias en el corpus testamentario medieval gallego. Una primera aproximación al tema realizada por Miguel García-Fernández lleva a afirmar que, teniendo en cuenta las dificultades que se presentan en cuanto a la asignación de una determinada categoría social u otra a un individuo concreto, los testamentos y documentos afines otorgados por miembros de la aristocracia constituyen un $36 \%$ del total examinado - 669 documentos - a los que habría que sumar gran parte de los otorgados por eclesiásticos - los cuales representan el 18\% - ya que la mayoría de estos pertenecían a familias situadas en diversos niveles de la pirámide nobiliaria gallega: Miguel García-FernándeZ, As mulleres nos testamentos galegos da Idade Media, tesis de licenciatura inédita, Santiago de Compostela, Universidade de Santiago de Compostela, 2012, págs. 31-35 y 87.

5 Sin pretender realizar un balance historiográfico sobre el tema, se pueden señalar a modo de ejemplo alguno de los numerosos estudios que han utilizado los testamentos como fuente principal: desde grandes clásicos como Jacques ChiffoleAu, La comptabilité de l'au-delà. Les hommes, la mort et la religion dans la région d'Avignon à la fin du Moyen Âge (vers 1320 - vers 1480), Roma, École Française de Roma, 1980 y obras de referencia como Susana Royer DE CARDInAL, Morir en España: Castilla Baja Edad Media, Buenos Aires, Universidad Católica de Argentina, s.f., o María del Carmen CARLÉ, Una sociedad del siglo XV. Los castellanos en sus testamentos, Buenos Aires, Universidad Católica Argentina, 1993, hasta contribuciones más recientes y con nuevos planteamientos, como Laura VIVANCo, Death in fifteenth century Castile. Ideologies of the elites, Suffolk, Rochester, Nueva York, Tamesis, 2004 o Mireia Comas VIA, Les dones soles a la Baixa Edat Mitjana: una lectura sobre la viduïtat, tesis doctoral inédita, Barcelona, Universitat de Barcelona, 2012, —agradecemos a la autora el acceso a la misma-. A estas obras habría que sumar diversas monografías regionales, dedicadas fundamentalmente al tema de la muerte, tales como Amparo BeJARANo RuBio, El hombre y la muerte: los testamentos murcianos bajomedievales, Cartajena, Ayuntamiento de Cartajena, 1988; Herminia Vasconcelos VILAR, A vivência da morte no Portugal medieval: a Estremadura portuguesa (1300 a 1500), Redondo, Patrimonia, 1995; María Luz Rodríguez Estevan, Testamentos medievales aragoneses. Ritos y actitudes ante la muerte (siglo XV), Zaragoza, Ediciones 94, 2002; Jaume Casamituana i Vilaseca, El testamento en la Barcelona bajomedieval. La superación de la muerte patrimonial, social y espiritual, Pamplona, Universidad de Navarra, 2004; Julia Pavón Benito y Ángeles García DE la Borbolla, Morir en la Edad Media. La muerte en la Navarra medieval, Valencia, Universitat de València, 2007 o, refiriéndose a una cronología más temprana, Nathaniel Lane TAYLOR, The will and society in Medieval Catalonia and Languedoc, 800-1200, Cambridge, Harvad University, 1995 y Linda Tollerton,
} 
mos con algunos estudios de notable interés que permiten atisbar algunas de sus posibilidades de estudio, así como diversas cuestiones metodológicas, pudiendo destacarse como referente básico de textos posteriores el trabajo dedicado a la muerte en la sociedad de la Galicia medieval de Ermelindo Portela y María del Carmen Pallares ${ }^{6}$. Precisamente, el tema de la muerte se ha convertido en un lugar común dentro de la historia de las mentalidades al influjo de los planteamientos metodológicos de la historiografía francesa ${ }^{7}$. Otras contribuciones como las de Francisco J. Pérez Rodríguez ${ }^{8}$, José Miguel Andrade ${ }^{9}$ o M. ${ }^{a}$ Luz Ríos $^{10}$, así como las de Carlos Calderón ${ }^{11}$, han enriquecido y matizado algunos aspectos

Wills and will-making in Anglo-Saxon, Rochester; Nueva York, York Medieval Press; Boydell Press, 2011 , sin contar el amplio número de artículos publicados en diversas revistas y obras colectivas a lo largo de las tres últimas décadas.

6 "Muerte y sociedad en la Galicia medieval (siglos XII-XIV)", en Manuel Núñez Rodríguez y Ermelindo Portela Silva (coords.), La idea y el sentimiento de la muerte en la historia y en el arte de la Edad Media, Santiago de Compostela, Universidade de Santiago de Compostela, 1988, págs. 21-29, y publicado inicialmente en Anuario de Estudios Medievales, 5 (1985), págs. 189-202.

7 Véase una aproximación historiográfica de carácter general en María AzPeitia Martín, "Historiografía de la "Historia de la Muerte", Studia Historica. Historia Medieval, 26 (2008), págs. 113-132. En lo que concierne al caso gallego, véase Ermelindo Portela Silva y María del Carmen Pallares Méndez, "Los espacios de la muerte", en De Galicia en la Edad Media..., págs. 101118, además del anteriormente citado "Muerte y sociedad..."; también María del Carmen PaLlaREs MÉNDEZ, "El sentimiento de la muerte y su influencia en la sociedad gallega bajomedieval", en Xavier Castro e Jesús de Juana (eds.), Mentalidades colectivas e ideoloxías. VI Xornadas da Historia de Galicia, Ourense, Deputación Provincial de Ourense, 1991, págs. 211-227. Incluso sobre el período pretestamentario se han hecho algunas consideraciones sobre el imaginario de la muerte, caso del trabajo de José Miguel Andrade Cernadas, Lo imaginario de la muerte en Galicia en los siglos IX al XI, Sada, Ediciós do Castro, 1992.

8 "Diferencias sociales más allá de la muerte. El recuerdo de los difuntos en la Galicia medieval (siglos XII-XV)", en ¿Quen manda aquí? O poder na historia de Galicia. VII Semana Galega de Historia, Santiago de Compostela, Asociación Galega de Historiadores, 1999, págs. 127-142.

9 "Los testamentos como reflejo de los cambios de actitud ante la muerte en la Galicia del siglo XIV", Semata, 17 (2005), págs. 97-114 o "La violencia recordada. Confesiones testamentarias en la Galicia de finales de la Edad Media”, Semata, 19 (2007), págs. 65-77.

10 "Aproximación a los testamentos de la Catedral auriense (ss. XII-XIII): disposiciones terrenales y espirituales", Semata, 17 (2005), págs. 75-96.

11 "Mujeres, ideología y cotidianeidad en la Galicia de mediados del siglo XVI. Un estudio de caso: el testamento e inventario de bienes de la condesa de Altamira, doña Ana de Toledo", Revista de Historia, 3 (1992), págs. 107-128; "Testamentos, codicilos y escrituras públicas. Evolución de las formas y contenidos de la última voluntad femenina en Galicia (siglos XII-XV)", Minius, 15 (2007), págs. 7-32; "Cambios y persistencias en la mentalidad nobiliaria gallega en el tránsito de la Edad Media a la Moderna según la literatura testamentaria. Un estudio comparativo", Cuadernos de Estudios Gallegos, 54, núm. 120 (2007), págs. 171-188; "Doña Urraca de Moscoso: de la crónica a su testamento. Perfil de una noble gallega de la segunda mitad del siglo XV", La Aljaba, segunda época. Revista de Estudios de la Mujer, 11 (2007), págs. 211-228; y "Algunas notas sobre el patrimonio de la boticaria Elvira Pérez (Santiago, 1348)”, Estudios de Historia de España, X (2008), págs. 125-135. 
sobre la práctica testamentaria medieval, aunque ésta no ha llegado a convertirse en objeto de atención preferente y monográfico hasta tiempos recientes ${ }^{12}$. Sin embargo, persisten todavía importantes vacíos historiográficos ${ }^{13}$ y una carencia casi absoluta de corpora testamentarios con sus correspondientes análisis diplomáticos ${ }^{14}$.

Si se considera la estructura global de los documentos - en los que se combinan las partes formulares con otras de carácter dispositivo ${ }^{15}$ - , se puede cons${ }_{12}$ Por el contrario, los modernistas gallegos se han preocupado en diversas ocasiones del estudio
de los testamentos, pero, a veces, desde una perspectiva de combinación de análisis cualitativos
y cuantitativos que, en cierta manera, ha desenfocado planteamientos más ambiciosos y globales
que la propia fuente in extenso posibilita. Uno de los mayores especialistas en el tema es Domingo
Luis GonZÁLEZ LoPo, quien no olvida hacer interesantes consideraciones sobre los testamentos
bajomedievales en su obra, Los comportamientos religiosos en la Galicia del Barroco, Santiago de
Compostela, Xunta de Galicia, 2002.

${ }^{13}$ Tanto desde la perspectiva global de la historia social como desde la referida específicamente a la historia de las mujeres. Una primera aproximación a esta última cuestión es el proyecto doctoral en curso de Miguel García-Fernández, quien toma en consideración el conjunto de instrumentos vinculados con la práctica testamentaria - piezas editadas e inéditas-, conformando un corpus documental que supera el millar de documentos para estudiar, de forma monográfica y entre otras cuestiones, la posición y el papel de las mujeres en la sociedad medieval gallega. Se contempla, pues, a las mujeres como sujetos históricos y como objeto historiográfico, dado el protagonismo que adquirieron, junto con los hombres, en los documentos de últimas voluntades, no sólo como otorgantes, sino también como beneficiarias y albaceas. Para un acercamiento a los planteamientos de dicha tesis, parcialmente recogidos en el presente artículo, véase M. GARCía-FERnÁndEZ, As mulleres nos testamentos galegos.... Desde la perspectiva de la historia de la muerte en clave femenina, véanse también las consideraciones de Graciela Gómez Cid, "A morte feminina no Ourense baixomedieval", Diversarum rerum, 4 (2009), págs. 227-241.

${ }^{14}$ Las colecciones diplomáticas elaboradas sólo con determinados tipos documentales, como pueden ser los testamentos, no se contemplaban entre los criterios habituales, que atendían fundamentalmente a la personalidad del otorgante o a hechos o instituciones determinadas: véanse las Normas de transcripción y edición de textos y documentos, Madrid, Escuela de Estudios Medievales, CSIC, 1944.

${ }^{15}$ Aunque las partes de libre disposición revelan detalles más próximos a la realidad social de los testadores, los formulismos contenidos en los documentos de últimas voluntades se convierten en magníficos espejos de la mentalidad colectiva, de ahí la importancia de tenerlos en cuenta. Tampoco ha de olvidarse que, entre el individuo y la colectividad, se producen constantes interrelaciones que hacen difícil discernir entre lo original o exclusivamente personal y lo general o compartido en ámbitos como el de las creencias o el imaginario. De todos modos, hay que ser cautos en el tratamiento de las diversas cláusulas y expresiones de carácter formular contenidas en este tipo de documentos: su tratamiento ha de realizarse no de forma individual sino a partir del análisis conjunto de un amplio volumen de documentos. Así pues, teniendo en cuenta la existencia de un formulario tipo que sería utilizado por los escribanos pero también conocido y asimilado por los individuos, como se pone de manifiesto en los testamentos hológrafos, se puede establecer un análisis diacrónico -sólo viable en la larga duración- con el que tratar de percibir cambios y persistencias ligados a la religiosidad, a los aspectos materiales o la propia consolidación del testamento como documento que refleja unas determinadas formas jurídicas. Sin duda, ese es el aprovechamiento que se ha de buscar en el análisis de unas fórmulas notariales y no tratar de vislumbrar una espiritualidad personal e 
truir un completo repertorio de temas que, considerados en su conjunto, permiten un estudio amplio de la nobleza gallega desde ópticas diversas, a la vez que complementarias, y que abarcan desde la historia social propiamente dicha hasta la historia cultural, económica y de las mentalidades. A pesar de esto, se ha acusado a los testamentos de reflejar sólo un momento muy concreto de la vida de los individuos, pero no cabe duda de que el retrato global que presentan para el periodo medieval es muy superior al ofrecido por otras fuentes, confluyendo tres tiempos en un mismo acto: el presente de la vivencia y el pensamiento de la muerte; el pasado de la vida recordada; y el futuro de los deseos del mañana ${ }^{16}$. Además, la lectura atenta de los testamentos revela un panorama lleno de dinamismo, derivado de la construcción de las más diversas relaciones sociales, económicas y de poder en torno a unos hombres y mujeres plenamente integrados en su contexto y sociedad.

El saber por qué se testaba y, sobre todo, cómo se materializaba el otorgamiento de las últimas voluntades en la Edad Media no son cuestiones baladíes. Los objetivos de los testamentos eran varios pero, principalmente, se trataba de organizar la transmisión de la herencia, muchas veces con el deseo de evitar los numerosos pleitos y desavenencias que surgían por ella. Al mismo tiempo, se aspiraba a garantizar la salvación del alma, tal y como recomendaban las autoridades eclesiásticas en numerosos sínodos y concilios bajomedievales. A ello se sumaban otros objetivos como los de premiar a aquellos que habían servido y apoyado en vida a los testadores o contribuir a la conservación de la memoria individual, la memoria genealógica y el orgullo del linaje ${ }^{17}$. Las disposiciones relativas a estas cuestiones podían ser otorgadas en el lecho de muerte o simplemente en previsión de la misma ${ }^{18}$, y acostumbraban a realizarse ante una autoridad notarial, dando lugar a documentos con una estructura más o menos común,

individualizadora, como es bien sabido: Rafael SÁNCHEZ SESA, "Modelos de muerte y mentalidad religiosa en la península ibérica. Los testamentos entre las élites castellanas de la segunda mitad del siglo XIV a la segunda del XV", Ilu. Revista de Ciencias de las Religiones, 5 (2000), pág. 169.

${ }^{16}$ M. García-FernándeZ, As mulleres nos testamentos galegos..., pág. 10, nota 7.

${ }^{17}$ E. Pardo de Guevara y VAldés, De linajes, parentelas y grupos de poder..., págs. 175-202.

${ }^{18}$ A este respecto se ha convertido en un lugar común analizar el estado de salud de los testadores. De todos modos, más allá de si otorgaron sus últimas voluntades estando sanos o enfermos, es importante ver en qué circunstancias concretas lo hicieron. De hecho, aunque en algunos casos el testador o testadora están sanos, se contempla la cercanía o posibilidad de la muerte ante el inicio de un viaje o por una condena a la pena capital. En este sentido, podemos destacar, además de casos célebres como el del Mariscal Pardo de Cela, el de los hermanos Alfonso y Vasco Gómez de Parada, que otorgaron sus testamentos el 22 de enero y el 27 de febrero de 1331 respectivamente: Xesús Ferro Couselo, A vida e a fala dos devanceiros. Escolma de documentos en galego dos séculos XIII ao XVI, Vigo, Galaxia y Fundación Penzol, 1967, vol. 1, docs. 51 y 52, págs. 80-82. 
lo que ha llevado a diversos autores a postular la existencia de formularios que, para el caso gallego, no conservamos ${ }^{19}$.

En el corpus gallego son habituales diversos tipos de testamentos. En cuanto a su soporte, podemos diferenciar entre el escrito y el oral, igualmente válidos si se cumplen una serie de requisitos formales, basados fundamentalmente en la presencia de testigos. Respecto a los testamentos escritos, éstos podían ser elaborados por un escribano ante testigos o, los menos, hológrafos, es decir, redactados por el propio testador. En los códigos legislativos también se hace referencia a una serie de formas especiales de testamentos, como los otorgados por viajeros o, en relación a la nobleza, los redactados por hombres de armas, cuyas últimas voluntades podían carecer de testigos y de parte de los formulismos y requisitos habituales ${ }^{20}$. Por otra parte, ha de tenerse en cuenta que se podían otorgar diversos testamentos a lo largo de la vida, lo que permite comparar los cambios que se produjeron entre unos y otros para tratar de explicarlos en relación a los acontecimientos que separaban ambos actos ${ }^{21}$, si bien son mucho más frecuentes las rectificaciones, precisiones o complementos parciales que no invalidaban el testamento, sino que daban lugar a la concesión de uno o varios codicilos.

\footnotetext{
${ }^{19}$ Es necesario señalar que la estructura de los testamentos gallegos responde en líneas generales a la misma que encontramos en el resto de la Corona de Castilla o de otros territorios del Occidente medieval, donde, a grandes rasgos, podemos diferenciar tres partes principales: el protocolo o preámbulo, las disposiciones testamentarias propiamente dichas y el escatocolo. Véase, a modo de ejemplo comparativo, Juan Carlos MARTíN CEA, "El modelo testamentario bajomedieval castellano y su reflejo en los diferentes grupos sociales", Edad Media. Revista de Historia, 6 (2003-2004), págs. 103-156. De todos modos, esto no está reñido con la capacidad de "personalizar" estos documentos en función de las circunstancias de los testadores, es decir, el notario o jurista no oculta al otorgante. A veces las últimas voluntades se han conservado en minutas, es decir, en forma de borradores realizados con anterioridad a la formalización definitiva de los documentos, cuyo contenido permite detectar, en buena medida, cuáles eran los formulismos de los testamentos medievales. Véanse a modo de ejemplo los docs. 35 y 38 en relación con la minuta transcrita en el doc. 51 en Pablo S. Otero Piñeyro Maseda, Colección documental del Archivo de la Casa de Otero de Quiroga (siglos XIII-XVIII), Lugo, Publicaciones de la Diputación Provincial de Lugo, 2007 (Col. Historia), págs. 103-105, 108-111 y 134-137, respectivamente.

${ }^{20}$ M. García-FernándeZ, As mulleres nos testamentos galegos..., pág. 22.

${ }^{21}$ Entre la nobleza gallega sabemos que, al menos, Sancho [Sánchez] de Ulloa, I conde de Monterrey, otorgó testamento en dos ocasiones, la primera en 1480 y la segunda en 1505 . Véanse respectivamente en Colección de documentos históricos del Boletín de la Real Academia Gallega, La Coruña, Real Academia Gallega, 1915, vol. I, doc. 108, págs. 307-316 y Colección Diplomática de Galicia Histórica, Santiago de Compostela, Tipografía Galaica, 1901, doc. 76, págs. 324-347. Otro caso que pone de manifiesto que no se trataba de algo excepcional es el de don Pedro Fernández de Castro, quien otorgó un testamento en 1337 deseando ser enterrado en el monasterio de Sobrado y, menos de tres años después, dispuso otro eligiendo a la catedral compostelana como sede para el descanso de su cuerpo: E. Portela Silva y M. ${ }^{a}$ C. Pallares Méndez, De Galicia en la Edad Media..., págs. 107-108.
} 
Los testamentos permiten una aproximación individual, pero también colectiva, a aquellos que integran el grupo parental nobiliario; por ello, una de las primeras dificultades que se plantean a la hora de analizar esta fuente es clarificar quiénes son y quiénes no miembros de dicho grupo. Junto a los hombres y mujeres de los grandes linajes, existe también una constelación de individuos nobles que no resulta sencillo situar en la pirámide nobiliaria, de ahí la necesidad de clarificar y establecer la posición que ocupaban en la jerarquía social y los grupos de poder. Es aquí donde el empleo de las técnicas prosopográficas y genealógicas encuentra su sentido en el estudio del grupo noble: reconstruir las filiaciones y parentelas en las que se integraron caballeros, eclesiásticos de diferente jerarquía o el complejo grupo de los escuderos ${ }^{22}$ tiene una utilidad que excede la simple erudición. Este sistema permite situar a los individuos en su contexto, estirpe y grupo parental, facilitando notablemente aproximaciones de todo tipo y, sobre todo, contribuye a avanzar con firmeza en la historia social de la nobleza ${ }^{23}$.

La propia presentación de los individuos tiene una significación determinante con el empleo preciso de tratamientos como el don o dona, cuestión que no resulta de poca importancia en el seno de una sociedad fuertemente jerarquizada como la medieval ${ }^{24}$. A ello se suman las propias referencias o costumbres onomásticas, tanto del otorgante como de los beneficiarios identificados como miembros de la familia o del grupo parental: además de que permiten conocer las tradiciones y modas antroponímicas ${ }^{25}$, sitúan a los individuos en el linaje, de ahí el interés por precisar las cadenas onomásticas y las homonimias ${ }^{26}$.

\footnotetext{
${ }^{22}$ Algunas consideraciones generales sobre estos escuderos en Pablo S. Otero Piñeyro Maseda, "O apoxeo dos escudeiros na Galiza baixomedieval. O caso dos Vilariño. O seu patrimonio e parentelas", História. Revista da Faculdade de Letras, 10 (2009), págs. 129-131.

${ }^{23}$ Eduardo Pardo de Guevara y ValdÉs, “¿Hacia una nueva ciencia genealógica? Reflexiones para una renovación en sus métodos y objetivos”, Medievalismo, 2 (1992), págs. 171-183 y “Es posible una nueva Genealogía?", en De linajes, parentelas y grupos de poder..., págs. 33-44; ofreciendo ya un panorama general sobre la pirámide nobiliaria gallega, véase del mismo autor "De las viejas estirpes a las nuevas hidalguías. El entramado nobiliario gallego al fin de la Edad Media", en De linajes, parentelas y grupos de poder..., págs. 47-70.

${ }^{24}$ Jaime de SAlazar y Acha, Génesis y evolución histórica del apellido en España: discurso leído el día 26 de mayo de 1991 en el acto de su recepción pública..., Madrid, Real Academia Matritense de Heráldica y Genealogía, 1991 y María Gloria de Antonio Rubio, "Onomástica y uso del «Don» entre los judíos gallegos medievales", Estudios de genealogía, heráldica y nobiliaria de Galicia, 3 (2004), págs. 433-452.

${ }^{25}$ Por ejemplo, la difusión de nombres de tradición artúrica: véase Isabel Beceiro Pita, "Modas estéticas y relaciones exteriores: la difusión de los mitos artúricos en la Corona de Castilla (s. XIII - comienzos s. XVI)", En la España medieval, 16 (1993), págs. 135-168.

${ }^{26}$ Una aproximación al tema en Eduardo Pardo de Guevara y VAldÉs, "Identidad y memoria genealógica. Una aportación al estudio de la antroponimia medieval gallega", en De linajes, parentelas y grupos de poder..., págs. 71-94.
} 
La identificación de los personajes y su integración en el conjunto de relaciones sociales y patrimoniales que surgieron a su alrededor constituyen procesos imprescindibles para reconstruir la genealogía de las familias de los grandes nobles, caballeros y escuderos que conformaban la pirámide nobiliaria gallega, al mismo tiempo que permiten comprender mejor el funcionamiento y la estructura interna del grupo al contribuir a clarificar las redes de relaciones trazadas tanto con otros individuos como con instituciones u órdenes ${ }^{27}$. Partiendo de la figura de los testadores, el estudio de su realidad personal y sus relaciones familiares resulta de gran interés con el objetivo de contribuir a la caracterización de las estructuras de parentesco y de las estrategias matrimoniales que ponía en marcha la nobleza medieval, pese a las limitaciones que presentan en lo que concierne al estudio de la nupcialidad, natalidad o mortalidad infantil ${ }^{28}$.

Además de las relaciones matrimoniales, que oscilaron entre el conflicto y la cordialidad ${ }^{29}$, el estudio del grupo noble ha de incluir las relaciones materno y paterno filiales, pues en ellas entran en liza, junto a los propios sentimientos ${ }^{30}$,

${ }^{27}$ Aragón en la Edad Media: la prosopografía como método de investigación sobre la Edad Media: sesiones de trabajo, Zaragoza, Universidad de Zaragoza, Departamento de Historia Medieval, Ciencias y Técnicas Historiográficas, 2006, pág. 5.

28 Ana María Framiñán Santas y Antonio Presedo Garazo, "Estructuras de parentesco de la nobleza gallega en 1350-1600: una primera valoración”, Obradoiro de Historia Moderna, 14 (2005), págs. 109-140.

${ }^{29}$ Un posible indicio sobre la armonía conyugal se puede encontrar en el nombramiento del cónyuge como heredero, tutor de los descendientes -incluso de los ilegítimos-o albacea testamentario. Sin duda, son de cuestiones a tener en cuenta, especialmente cuando afectan al nombramiento de las mujeres como herederas de sus maridos, tutoras de los hijos y cumplidoras testamentarias. De todos modos, se trata de indicios que no han de verse como relaciones causales directas y que han de ser puestos en relación con la existencia de unas determinadas prácticas jurídicas y costumbres sociales. Aún así, puede resultar ilustrativo como ejemplo de ruptura de esa armonía conyugal que don Bernardino Pérez Sarmiento, conde de Ribadavia y Adelantado Mayor de Galicia, nombrase como tutores de sus hijas y herederas en 1493 a "Alonso de Carrion e Juan de Collantes, mis criados e alcaydes" y no a su mujer y madre de las niñas, doña María Pimentel de Castro, a la que tampoco nombra como albacea, cargo para el que también designa a los anteriormente citados. Sin duda, en este hecho habría influido que existiese una sentencia de nulidad sobre su matrimonio y que doña María lo hubiese acusado ante los Reyes Católicos de "la aver maltratado" y haberla apremiado a que solicitase el "divorçio del dicho matrymonio, disiendo que vos antes que con ella casasedes, herades desposado por palabras de presente". No obstante, don Bernardino aún contempla la posibilidad de llegar a tener un hijo con doña María y le deja a la misma una serie de rentas: Gonzalo Francisco Fernández SuÁreZ, La nobleza gallega entre los siglos XIV-XV. Los Sarmiento Condes de Ribadavia, Santiago de Compostela, El Eco Franciscano, 2002, págs. 248-250 y doc. 48, págs. 537-549.

${ }^{30}$ Estos habrían tenido una importancia especial no sólo en el caso de los hijos legítimos, sino también en el de los hijos ilegítimos; al fin y al cabo, muchas veces estos últimos eran recordados con el objetivo de legarles algunos bienes y ofrecerles algún tipo de amparo y protección: en 1454, Paio Gómez de Sotomayor nombra en su testamento "ao doutor Diego Albarez que oube de ganança de Maria Gomez mina serventa”: Colección Diplomática..., doc. 107, págs. 460-471. También Fernán 
cuestiones como la necesidad de ordenar el patrimonio conforme a los intereses del linaje $e^{31}$, la tutoría o los conflictos ${ }^{32}$. Se trata muchas veces de clarificar, por tanto, quiénes heredaban, siendo fundamental examinar el proceso de aparta-

García Barba de Figueroa se acuerda de un hijo habido fuera del matrimonio: se trata de Fernán García Galego "que eu sendo moço solteiro ouben de Lourença Albres da fregesia de Alba criada que foi do meu señor padre". En este caso no es el fruto de una relación extramatrimonial, sino de una habida con anterioridad; por ello, no es de extrañar que ya le haya "dado os bees e rendas que eu habia enna dita fregesia e mando que os meus conpridores e fillos e erdeiros non lle tollan cousa algunha do que ansi lle teño dado porque non he mais do que debia darlle por sua porçion como tal meu fillo bastardo antes quero que lo anparen e ajuden e defendan en elo": Colección Diplomáti$c a \ldots$, doc. 8, págs. 27-34. En otras ocasiones resulta especialmente difícil interpretar el sentido de las mandas por su falta de claridad, de ahí que sea imprescindible conocer bien el grupo parental y trayectoria del individuo; es el caso del testamento de Fernán Fernández de Chamoso otorgado en 1450: en él hace legados a una María Fernández, otros diversos a una "minna filla" cuando "for de ydade", y deja como "legitimo" heredero en el resto de sus bienes y como cumplidor testamentario a un Fernán Fernández Parragués "meu parente": P. S. Otero Piñeyro Maseda, Colección documental del Archivo de la Casa de Otero..., doc. 34, págs. 100-103.

${ }^{31}$ Resulta fundamental analizar las mejoras y el proceso de implantación de los mayorazgos, recursos fundamentales para la supervivencia y la reproducción social del grupo, pero siempre sin olvidar la trayectoria social y económica de los linajes nobles, evitándose así generalizaciones desenfocadas en un grupo social tan heterógeneo y jerarquizado como es el privilegiado. En este sentido, conviene destacar lo tardío de la consolidación del modelo reproductivo basado en el mayorazgo: Antonio Presedo Garazo, "Los logros materiales y simbólicos de una mujer noble en Galicia a comienzos de la época moderna: Doña Violante de Andrade (c. 1484-1538)", Semata, 20 (2008), págs. 191 y 210.

${ }^{32}$ A veces estos podían culminar en casos de desheredamiento, como sucedió a comienzos del siglo XVI a Álvaro González de Ribadeneira y su mujer María de Bolaño con dos de sus hijas, al haberse casado "con personas vajas": Xosé Antón García GonZÁlez-Ledo, "Testamentos do mariscal Álvaro González de Ribadeneira e a súa muller María de Bolaño (século XVI)", Estudios Mindonienses, 23 (2007), págs. 845-873. Otro caso paradigmático es el de don Giraldo, que en 1302 explica detalladamente los motivos que le llevaron a desheredar a "meu fillo Estevoo Perez [que] me mandou desonrrar por çinquo vezes, estando eu doente en Sande, sobre los meus dineyros (...) et porque poso a mao en o coytelo para vir contra min, et porque verteu a Juan Fernandes do Paazo, meu home, una cuba de viño ante min (...) et porque prendeu < $>$ Martin Domínguez de Varbantes, meu ome, et levou del mill et quatroçentos et çinquenta maravedis, et porque fillou a moller et afillo a Lourenzo Martinez de Prado meu home, et levou delos mill et quatrocentos maravedís, et porque prendeu <a> Juan Baralla, meu ome, et me britou dous dentes na boca (...) et forzou una mia vasalla, manzeba en Cabelo, chamandose a mi, et por una casa que me queimou en Revoreda, et por quinse moyos de pan que me tomou en Revoreda (...) et porque me chamou en juyzo por ante o ynfante don Felipe sobre lo meu, et por outros exerdamentos et desonrras muitas que me fiz, exeredoo de todos los meus beens movil et rayz, tanben do que lle deu mina madre como de quanto eu conprey et ganey, asi o exheredoo dos yglesarios como dos coutos, como dos enprazamentos, como das gaanzas, como a todas las outras cousas que eu ey, et ençima aia a mina maldiçon et a de Deus Padre poderoso (...)": Miguel Romaní Martínez, "El monasterio cisterciense de Santa María de Melón. Observaciones sobre los Tumbos 323, 324 y 325 del Archivo Histórico Nacional. Los testamentos de don Giraldo y de Alonso Yanes Churruchao", Boletín Auriense, 41-42 (No lembrar Olga Gallego Domínguez), vol. 1 (2011-2012), doc. 1, págs. 269-270; también en X. FerRo Couselo, A vida e a fala dos devanceiros..., vol. 1, doc. 39, págs. 54-57. 
miento -o no- de las mujeres respecto al grueso de la herencia, la cual parece ir concentrándose progresivamente en una línea de la familia, fundamentalmente la representada por los varones y privilegiando la primogenitura ${ }^{33}$. Pese al reforzamiento de la verticalidad sobre la horizontalidad que dio lugar a la consolidación de los linajes al menos desde el siglo XIV, el grupo parental siguió teniendo un papel fundamental sobre el que es necesario profundizar ${ }^{34}$. De lo que no cabe duda es del importante caudal informativo que nos aportan los testamentos para conocer con mayor detalle el fenómeno de la construcción de los linajes, lo cual aparece ligado a la existencia de una división no igualitaria de la herencia, la constitución de mayorazgos, la entrega de mejoras, la transmisión y uso de los signos de identidad del grupo ${ }^{35} \mathrm{y}$, en definitiva, al progresivo establecimiento de una jefatura definida sobre la casa noble, que apostó por privilegiar con el tiempo la llamada varonía ${ }^{36}$. Todos estos procesos se pueden seguir con atención en los testamentos de la época medieval y del Renacimiento, contribuyendo su relectura y análisis a ratificar, matizar o cuestionar lo que otras fuentes más parciales, como los llamados nobiliarios, pretendieron transmitir con una fuerte influencia ideológica de sus autores y del propio grupo aristocrático ${ }^{37}$.

En la reconstrucción de las redes de relaciones que se fueron tejiendo en torno a los miembros de la nobleza gallega y entre ellos mismos y diversas instituciones $^{38}$, la metodología del Network Analysis se convierte en una herramienta

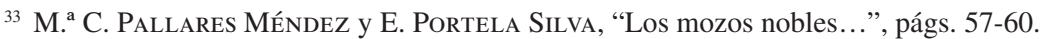

34 E. Pardo de Guevara y VAldés, De linajes, parentelas y grupos de poder... págs. 55-59.

35 Álvaro Fernández de Valladares en su testamento de 1397 condiciona la transmisión de la herencia - siempre y cuando hubiesen fallecido sus hijos legítimos — al hijo de su hermana Sancha Rodríguez al hecho de que "tome as armas et o apelido de Valadares, et non no fasendo que seja destribuydo hu viren que he proveyto de minna alma": véase doc. 1. Sin duda, las armas y el apellido constituían referentes ineludibles en el proceso de identificación y consolidación del linaje.

${ }^{36}$ La cristalización de los linajes medievales gallegos, con las consecuencias que se derivaron de la implantación de los mismos en la reorganización de las relaciones entre los miembros de la familia noble, habría que situarla en torno al siglo XIV, tal y como han señalado E. Portela Silva y M. ${ }^{\text {a }}$ C. Pallares Méndez en De Galicia en la Edad Media..., págs. 261-276. A partir de los primeros indicios apuntados, será sobre todo durante los siglos XV y XVI cuando se perciba en Galicia con mayor nitidez el funcionamiento de la organización linajística y la consolidación de prácticas como la del mayorazgo o vinculación de bienes. Para los casos castellano y leonés véanse los estudios de Isabel Beceiro Pita y Ricardo Córdoba de la Llave, Parentesco, poder y mentalidad. La nobleza castellana. Siglos XII-XV, Madrid, CSIC, 1990, e Inés CALdERón Medina, Cum magnatibus regni mei. La nobleza y la monarquía leonesas durante los reinados de Fernando II y Alfonso IX (1157-1230), Madrid, CSIC, 2011 (Biblioteca de Historia, 74), págs. 64-73.

${ }_{37}$ María del Pilar PAREdes Mirás, Mentalidade nobiliaria e nobreza galega. Ideal e realidade na Baixa Idade Media, Noia, Toxosoutos, 2002.

${ }^{38}$ En especial con las instituciones religiosas, lo que debe analizarse en el marco de un conjunto de intereses que podían abarcar desde la religiosidad y el patronazgo hasta las prácticas de encomienda, los intereses económicos o la existencia de relaciones familiares con miembros que formaban
} 
sumamente útil. De este modo, se pueden representar de forma visual los resultados, diferenciando los diversos grados de densidad que se presentan dentro de la red de relaciones y clarificando el universo social de la nobleza gallega, donde, además de las solidaridades de grupo o de género ${ }^{39}$, se documentan las relaciones de dependencia y de amistad ${ }^{40}$. Por todo ello es necesario tomar en consideración al amplio número de individuos de cualquier estado o condición citados en los testamentos - deudores, acreedores, albaceas o cabezaleiros testamentarios, nóminas de testigos, criados, clérigos - y no sólo a los beneficiarios de los diversos legados que se disponen en las últimas voluntades ${ }^{41}$. Siguiendo lo señalado por

parte de dichas instituciones: E. PARDo de Guevara y VAldÉs, De linajes, parentelas y grupos de poder..., págs. 363-403.

${ }^{39}$ En la Edad Media resulta habitual la transmisión de bienes a los congéneres en el marco de una sociedad donde la asignación de determinados papeles sociales en función de la pertenencia de los individuos a uno u otro sexo tenía plena vigencia. De este modo, muchos caballeros y escuderos recibían de sus señores algunas armas, y las mujeres acostumbraban a recibir ropas de sus señoras: Rodrigo de Sandoval dispuso en sus últimas voluntades, otorgadas en 1427, que diesen a "Juan Baya o meu arnes de pernas e os gardabraços e os gadaos" y a otro de sus criados "Guterre que lle den dineros para huun arnes de pernas"; sin embargo, no olvida dar a "Tareija Lopes, miña serventa quinientos maravedís de moneda vella para ajuda de casamento" y a "estas molleres que aquí están en casa Sancha e Lionor, sua filla, e Maria Peres a cada huna seu pelote de paño de morilla": G. F. Fernández Suárez, La nobleza gallega ..., doc. 10, págs. 327-335. Pero, esto no excluye la transmisión de otro tipo de bienes sin que entrase en juego la diferencia de género.

${ }^{40}$ En 1327, Afonso Yáñez Churruchao hace referencia a la larga relación que le une a "Juan Noteiro, notario de Louriña polo serviço que ele et seu padre feceron a min et a meu hirmán Pero Eanes et a miña madre dona Elvira", por lo que le manda "duçentos maravedís de esta dita moneda alfonsi $<$ de $>$ X dineiros pollo maravedí”, sin contar con otros tantos que recibiría por el otorgamiento de la escritura testamentaria: M. Romaní Martínez, "El monasterio cisterciense de Santa María de Melón...", doc. 2, pág. 272; testamento también editado en Ermelindo Portela SiLVA, La región del obispado de Tuy en los siglos XII a XV. Una sociedad en la expansión y en la crisis, Santiago de Compostela, El Eco Franciscano, 1976, doc. 49, págs. 396-401. En otros casos, lo que se pretende es pagar las soldadas atrasadas a los miembros del servicio de la residencia, o simplemente organizar la casa tras la muerte del señor. En este sentido, doña Teresa de Zúñiga dispuso en 1470 que "mando que por quanto yo la dicha Condesa tengo muchos cargos, asy de mis criados e criadas e basallos como de otras personas, mando que con consejo del señor Conde de Plasençia, mi señor primo, e de mi hermano Juan de Estuñiga e de mi fijo el Conde e de mi padre frey Juan Maestro a los quales dexo por mis testamentarios, todos quatro e maçesores, que ellos todos quatro juntamente e los dos dellos y el señor Conde de Plazençia por sus grandes negoçios no podiere entender en ellos, que los dichos dos dellos tengan todo el cargo juntamente e lo puedan hordenar e mandar como yo mesma”: G. F. FernándEZ SuÁREZ, La nobleza gallega ..., doc. 31, págs. 452-456.

${ }^{41}$ Definir este rico universo de relaciones sociales solo será posible con el detenido estudio de un amplio corpus que permita rebasar lo individual y detectar los comportamientos generales en los grupos parentales de condición semejante. A modo de ejemplo, se pueden señalar diferentes casos que demuestran la diversidad de posibilidades; en el testamento de Álvaro Fernández de Valladares (véase doc. 1), ambos albaceas pertenecen al estamento eclesiástico: "Juan Nunes, tesorero de Tuy, et a Lopo Rodrigues, arçidiano de Montes". También figuran dos clérigos entre los testigos, a los que se suman otras personas de las que se desconoce su origen o posición. En el caso de Teresa de Meira (véase doc. 2), los albaceas son "meus fillos Gregorio de Valadares et a Diego Suares", 
Domingo González Lopo para las mandas de época moderna, el testamento se convierte, en manos del historiador, en el ventanuco, o el ventanal, según los casos, por el que podemos asomarnos a una parcela de la realidad vivida del pasado, no sólo por parte del otorgante, sino también de sus familiares, amigos, vecinos y paisanos, a cuyo silencio él está poniendo voz ${ }^{42}$.

\section{LA TRANSMISIÓN DEL PATRIMONIO}

En la mayoría de los casos, queda constancia de las relaciones a las que se acaba de hacer referencia como consecuencia del deseo del testador de entregar una parte de su patrimonio a sus allegados. No se debe olvidar que además de una función religiosa, los testamentos trataban sobre todo de organizar la transmisión de bienes. Del análisis de los documentos se puede concluir que el grueso de los mismos se destinaba a la reproducción social del grupo, así como a la conservación de la memoria propia y la de los parientes próximos, sin contar con las inversiones en la consecución de méritos para el alma o los legados en beneficio de las instituciones y personas con las que establecían diversos tipos de relaciones ${ }^{43}$. Es importante resaltar que las referencias cuantitativas o

mientras que sólo se citan como testigos a dos moradores de Vigo "et outros". Más significativo es el caso de Gregorio de Valladares (véase doc. 3), quien no duda en nombrar como cumplidor testamentario, además de pedirle que "tenan cargo de meus fillos et do seu en quanto foren menores", al "viscond<e> de Finsterra, meu sennor"; por el contrario, ningún familiar o religioso parece figurar entre los testigos. Más allá del caso de los Valladares, en 1427, el anteriormente citado Rodrigo de Sandoval, merino mayor de Galicia, otorgó su testamento nombrando como albaceas a los escuderos Pedro López Mosqueira y Fernando de Torres, al mismo tiempo que entre los testigos figuran un religioso del monasterio de San Clodio do Ribeiro, Vasco Gómez, regidor de Orense, frey Gómez, ministro de la iglesia de Santa Marta de Ribadavia, Vasco Rodríguez "notario do dito Rodrigo de Sandoval" y frey Ruy, fraile del monasterio de Santo Domingo de Ribadavia: G. F. Fernández SuÁrez, La nobleza gallega ..., doc. 10, pág. 327-335. Por otro lado, doña Beatriz de Castro, mujer de la élite urbana orensana, que otorgó su testamento en 1478 viuda y sin hijos, nombró como cumplidores testamentarios a dos religiosos: "Goterre Gonçalvez, clérigo de Soutomayor, e a Afonso Fernandez, canónigo d'Ourense"; entre la nómina de testigos figuran una serie de personas de diversa procedencia y oficio con las que no se pueden establecer, por el momento, vínculos concretos: el licenciado Alfonso Sánchez de Fermosilla, vecino de Valladolid — pese a que el testamento se realiza en Orense-, un zapatero, un sastre, un morador de Soutomaior y varios vecinos de la ciudad, "et outros para esto chamados et especialmente rogados": M. GARCíA-Fernández, As mulleres nos testamentos galegos..., doc. 39, págs. 187-188 y "Doña Beatriz de Castro: una mujer con nombre propio en el siglo XV ourensano", en Clara Elena Prieto Entrialgo (ed.), El mundo urbano en la España cristiana y musulmana medieval, Oviedo, Asturiensis Regni Territorium, 2013, págs. 159-174.

${ }^{42}$ D. L. GonZÁlez Lopo, Los comportamientos religiosos..., pág. 66.

${ }^{43}$ Miguel García-Fernández, "Las Sarmiento: mujeres con poder al final de la Edad Media", en M. ${ }^{a}$ Isabel del Val Valdivieso y Cristina Segura Graiño (coords.), La participación de las mujeres en lo político. Mediación, representación y toma de decisiones, Madrid, A. C. Almudayna, 2011, pág. 144. 
incluso las propias relaciones medianamente exhaustivas del conjunto de los bienes que conformaban los patrimonios de los nobles son excepcionales. De hecho, se precisa advertir que lo más habitual es que en los testamentos figure el nombramiento de los herederos universales en el remanente de los bienes, es decir, de aquellos que restaban, en teoría, después de haber satisfecho o recibido las deudas pendientes, pagado los sufragios estipulados, organizado el funeral o enterramiento, entregado los diversos legados píos encargados y ejecutado las mandas a particulares ${ }^{44}$. Se debe tener también en cuenta que los conceptos de propiedad y posesión de los bienes mencionados en las mandas testamentarias son habitualmente soslayados: los testadores transmiten frecuentemente patrimonios que en realidad no les pertenecen, sino que sólo disfrutan de manera más o menos legítima, muchas veces como beneficiarios de contratos forales ${ }^{45}$. De la misma forma, es muy habitual que tomen el todo por la parte, es decir, que dispongan de bienes o derechos que en realidad no lo son en su totalidad, in solidum, sino sólo en alguna de sus partes: esta circunstancia se vislumbra muchas veces en la tenencia de cotos jurisdiccionales, beneficios y patronatos eclesiásticos, al mismo tiempo que en sus casas solares o pousas.

A pesar de estas dificultades, se puede, no obstante, reconstruir una parte de estos patrimonios atendiendo a cada uno de los capítulos expuestos, o también conocer por referencias indirectas el origen de dichas propiedades - herencias ${ }^{46}$, foros, compras, permutas, robos...- su naturaleza — gananciales, en plena propiedad, encomienda, usurpación, botín...- e incluso las formas de gestión de las mismas. Se trata de un conocimiento parcial, pero también extraordinario y sumamente útil, que permite entrecruzar o contrastar a posteriori noticias y datos ${ }^{47}$.

\footnotetext{
${ }^{44}$ En el testamento de Álvaro Fernández de Valladares (véase doc. 1) se dispone, tras otorgar diversos legados a monasterios, que "en todos los outros meus beens que esto que sobredito he et remanesçeren, faco ( sic) meus heredeyros universaes a Vasco Fernandes et a Pero Alvares, meus fillos". No figuran, en ese caso, los habituales legados a particulares que también habrían de restarse del grueso del patrimonio que heredarían los hijos, lo que hace suponer que el traslado que se conserva sólo contiene algunas cláusulas. Por el contrario, Gregorio de Valladares (véase doc. 3) sí que hace una relación amplia de disposiciones concretas a favor de diversos hombres y mujeres.

${ }^{45}$ En 1393, por ejemplo, Isabel Eáns, mujer de Gonzalo Pérez de Moscoso, dejó al monasterio de Santo Domingo de Bonaval "a mina parte do foro que eu ey enna casa en que soya morar Iohan de Deus, que esta enna Peña": Carmen Manso Porto, "El códice medieval del convento de Santo Domingo de Santiago (II)”, Archivo Dominicano, IV (1983), doc. 16, págs. 100-103.

${ }^{46}$ Incluso es posible tratar de reconstruir la transmisión de la herencia en sucesivas generaciones. Álvaro Fernández de Valladares, por ejemplo, recordaba en su testamento que unas propiedades que decidía donar a su hijo le pertenecían "por herença da minna madre donna Elvira, segundo que os ela herdava de seu padre Pedro Alvares et de sua madre dona Elvira": véase doc. 1.

${ }^{47}$ No se trata de una fuente definitiva pero sí apetecida, de ahí la inexcusable confrontación empírica, en especial con los documentos forales, muchas veces desdeñados sin demasiada sutileza y desde visiones historiográficas miopes: a este respecto véanse los comentarios de Isidro García Tato y Eleutino Álvarez Álvarez, Las encomiendas gallegas de la Orden Militar de San Juan
} 
Al margen de los límites que se nos plantean a la hora de analizar los patrimonios nobiliarios a través de los testamentos, conviene destacar que algunos de esos bienes pueden convertirse en magníficos indicios para el estudio de los niveles de vida de la nobleza gallega, lo que, al mismo tiempo, permite observar importantes diferencias y contrastes dentro de este grupo privilegiado que no siempre obedecen a la antigüedad y prestigio de la estirpe. Se hace necesario, por tanto, establecer la tipología de bienes que se mencionan en los testamentos, procediendo a una detenida y correcta lectura, cuasi arqueológica, de la cultura material referida en los mismos, y organizar dichos bienes, tanto los muebles como los inmuebles, en función de una serie de niveles de vida. Sin duda, las reiteradas menciones a objetos de oro y plata en los testamentos de algunos miembros de linajes históricos de la Galicia bajomedieval ${ }^{48}$ contrasta con las referencias más escuetas — si las hay — contenidas en las últimas voluntades de otros linajes con una proyección social y territorial aparentemente mucho más limitada. Se trata de otra manifestación más de la evidente heterogeneidad del grupo noble y de sus diferentes niveles de vida y renta, que debe repercutir en metodologías de estudio y perspectivas de análisis más locales y cronológicamente más definidas ${ }^{49}$.

Consideración especial ha de darse a la posesión de libros, de instrumentos y materiales de escritura, de documentos y arcas de archivos familiares, de instrumentos musicales, o también, incluso, de legados de librerías, pues, aunque no son pocas las reservas que se pueden plantear al respecto - la posesión no implica necesariamente su uso, aunque tampoco lo excluye-, constituyen un buen indicio sobre el nivel o preocupación cultural y alfabetización de la nobleza ${ }^{50}$. A

de Jerusalén. Estudio y edición documental. La encomienda de Quiroga, tomo 2-1, Santiago de Compostela, CSIC-Xunta de Galicia, 2010, págs. 16-17.

${ }^{48}$ Un ejemplo se puede ver en el doc. 2, en el que la testadora habla de diversos objetos de su propiedad que se encuentran, en el momento de su muerte, en manos ajenas; no duda incluso en reconocer que tiene empeñadas "catro doas de prata, as quaes doas som de Miçia, minna neta". En otros casos, dichos objetos de lujo son entregados en forma de legados píos, como hizo en 1442 doña María de Limia, mujer de Afonso Suárez de Deza, quien dispuso que diesen "el caliçe e patena e vestimenta de oro que teño en el dito mosteyro de Çelanoba que seja todo para o dito mosteyro para con que digan misas por miña alma e de Alonso Xuares, meu marido que Deus aja”: G. F. FERNÁndez SuÁrez, La nobleza gallega..., doc. 14, págs. 366-367.

${ }^{49}$ La heterogeneidad de "las noblezas" se analiza, por ejemplo, en los ya clásicos estudios de Marie-Claude Gerbet, entre los que destaca Las noblezas españolas en la Edad Media: siglos XIXV, Madrid, Alianza, 1997 (Alianza universidad, 871). También Ignacio Álvarez Borge, Poder y relaciones sociales en Castilla en la Edad Media: los territorios entre el Arlanzón y el Duero en los siglos X al XIV, [Valladolid], Junta de Castilla y León, Consejería de Educación y Cultura, 1996 (Col. Estudios de historia, Castilla y León. Consejería de Educación y Cultura), pág. 136.

50 Tampoco se debe olvidar el valor de los libros como objeto de lujo; en 1498 doña Urraca de Moscoso legó a su sobrino el Conde de Altamira su "libro nuevo de Rezar aluminado de oro, porque cuando Rezare por el se acuerde de mi”: José García Oro y María José Portela Silva, La Casa 
ello se suma, por ejemplo, la capacidad o no de firmar sus propios testamentos, o también la posibilidad de haberlos redactado ellos mismos, dando lugar a los llamados testamentos hológrafos, de los que se conservan algunos ejemplos ${ }^{51}$. Finalmente, el capítulo de las relaciones de la nobleza con la cultura no debe olvidar el ejercicio del patronazgo y el mecenazgo, que, en los testamentos, se vislumbra indudablemente vinculado a la consecución de méritos para la salvación del alma. De ese modo se pueden interpretar las mandas fundacionales de hospitales o de colegios, las concesiones de legados para las obras monásticas, catedralicias o parroquiales, la fundación de ermitas o capellanías e incluso las inversiones destinadas a la reparación de puentes, calzadas e infraestructuras urbanas.

\section{LA ACTITUD ANTE LA MUERTE}

Más allá de los aspectos familiares y patrimoniales que permiten conocer la vida de los testadores nobles y su entorno, uno de los temas más estudiados a partir de los testamentos — muchas veces el único- es el de la religiosidad y las actitudes ante la muerte: se trata de cuestiones como las disposiciones relativas al futuro del alma y aquellas otras que tienen como objetivo establecer el lugar y los modos de enterramiento. Asimismo, entran en juego asuntos como las devociones, los sufragios, la práctica de la piedad y las prescripciones relativas a la organización de los funerales. Y es que más allá del nombramiento de los herederos, los testamentos constituían documentos religiosos de primer orden, como ya se ha advertido con anterioridad. De hecho, se ha señalado en diversas ocasiones su consideración como pasaporte para la vida eterna ${ }^{52}$. Esto mismo convierte a los testamentos en una fuente de notable interés para estudiar temas vinculados a la esfera de lo mental y lo privado, pero que al mismo tiempo reflejan un conjunto de comportamientos colectivos, como sucede con el ejercicio de la piedad o, incluso, el arrepentimiento. Con el deseo de limpiar la pena de los pecados terrenales, los nobles gallegos trataban de reparar los daños, ofensas y ruidos ocasionados a lo largo de sus vidas ${ }^{53}$, al mismo tiempo que aspiraban a enumerar y a tratar de satisfacer las deudas pendientes, dando lugar a que la mayoría de los testa-

\footnotetext{
de Altamira durante el Renacimiento. Estudio introductorio y colección diplomática, Santiago de Compostela, El Eco Franciscano, 2003, págs. 96-105.

${ }^{51}$ Entre ellos se puede destacar el citado anteriormente, otorgado por doña Urraca de Moscoso: J. García Oro y M. a J. Portela Silva, La Casa de Altamira..., págs. 96-105.

${ }^{52}$ Philippe Ariès, La muerte en Occidente, Barcelona, Argos-Vergara, 1982, págs. 73-74.

53 Álvaro Fernández de Valladares, en su testamento otorgado en 1397, dispuso para el monasterio de Santa María de Melón, en el que mandaba ser sepultado, "tresentos maravedis et una [pitanza...] venco? que perdoe a min et a meus avos o que ouvemos do dito mosteyro", además de dar al de
} 
mentos contengan una exhaustiva nómina de deudas y deudores con las más variopintas cuantías, conceptos y objetos ${ }^{54}$.

La encomienda del alma a la divinidad y a un conjunto más o menos amplio de intercesores o abogados celestiales es uno de los elementos más característicos de la primera parte de los testamentos. Mediante esas disposiciones, a las que habría que añadir la concesión de legados píos a determinadas instituciones religiosas - aunque en ello confluyen diferentes intereses, algunos ya mencionados - se puede reconstruir a grandes trazos las devociones de la nobleza gallega. Junto a los formulismos y al nombramiento de la Virgen como intercesora por excelencia, los testamentos especifican, en mayor o menor detalle, una serie de santos, apóstoles, mártires y otros miembros de la corte celestial, como los ángeles y arcángeles, a los que se solicita su intercesión ante la divinidad, pudiendo ser considerados algunos de ellos como protectores del linaje $\mathrm{e}^{55}$.

Al mismo tiempo, la lucha a favor de la salvación del alma puede considerarse también como la batalla contra la muerte-olvido, dando lugar a la concesión de numerosos legados piadosos ${ }^{56}$, a la fundación de aniversarios $\mathrm{y}$, acentuándose ya conforme avanzamos hacia los últimos decenios de la Edad Media, a la institución de capellanías o capillas funerarias, recursos todos ellos con los que se trataba de contribuir a la llamada por Jacques Chiffoleau "matemática de la salvación" 57.

Santa María de Oya "tresentos maravedis, et ellos que perdoen a meus avoos et a min $<0>$ que ouvemos do dito seu mosteyro et a meu padre": véase doc. 1.

${ }^{54}$ Así se puede ver en el testamento de Teresa de Meira, otorgado en 1470, en el que declara diversas deudas: véase doc. 2 .

55 Algunas consideraciones generales en Isabel BeCEIRo PITA, "La aristocracia de Castilla y sus abogados celestiales", Estudios de Historia de España, 12 (2010), págs. 27-48. Mientras los Valladares se limitan a nombrar como interecesores a la "Virgen Santa Maria con todollos santos et santas da gloria do Parayso" (véase doc. 2) o, con una fórmula similar, a la "Virgen Santa Maria, sua madre, con toda a corte çelestial, que seja mina avogada" (véase doc. 3), en otros casos, como el de doña Beatriz de Castro, la nómina de intercesores se amplía notablemente: "Santa Maria con todaslas virgenes et a Santiago e a Sant Pero et a Sant Paulo con todoslos apostollos et a Sant Domingo et a Sant Françisco et a Sant Martino con todoslos confesores et a Sant Sebastian et a Sant Bertolameu et a Sant Lourenço con todoslos marteres et a todoslos outros santos et santas da gloria do Parayso": M. GArcíA-Fernández, "Doña Beatriz de Castro...”, pág. 170.

${ }^{56}$ Gregorio de Valladares (véase doc. 3) cita diversos centros monásticos e iglesias que se habrían de beneficiar de sus legados piadosos; entre ellos, los conventos de Santo Domingo, San Francisco y Santa Clara de Pontevedra, así como el de Santo Domingo de Tuy; los monasterios de San Juan de Poyo, Lérez o Armenteira; iglesias como San Bartolomé y Santa María la Grande, o capillas como Santa María do Camiño. Por otra parte no olvida a Santa María de Vigo, "onde jas mina madre". Y es que, sin duda, los legados píos de la nobleza estaban muchas veces condicionados por el recuerdo de sus ancestros.

57 J. Chiffoleau, La comptabilité de l'au-delá..., pág. 209 y ss. En el doc. 1 editado en estas páginas, Álvaro Fernández de Valladares especifica que de no existir descendencia legítima "que os 
Las inversiones eran más que considerables ${ }^{58}$, llegando a contarse por decenas, centenas o millares las misas y oraciones encargadas a diversas instituciones, entre las que poco a poco fueron destacándose los centros mendicantes, franciscanos y dominicos, como auténticos especialistas en el tema de la muerte ${ }^{59}$.

Entre la nobleza se observan dos grandes actitudes en cuanto a los modos de enterramiento: por un lado, se difunden comportamientos que aspiran a un entierro menos solemne y a actitudes más humildes, de ahí la elección de los hábitos religiosos como mortaja, especialmente el franciscano; mientras tanto, muchos otros desean ser enterrados conforme a su "estado o condición" 60 , dando lugar a verdaderos actos sociales en los que se reunían numerosos miembros del

ditos bens que os destribuyan os ditos meus conpridores con aqueles a que des (sic) deyxaren cargo se non foren bibos, et façan des capelas quaes vieren que se poden servir et manter por ellos".

${ }^{58}$ En 1403, don Diego Pérez Sarmiento, Adelantado Mayor de Galicia, dispuso en su testamento "que digan por mi alma veynte treyntanarios revelados. (...) otros treynta treyntanarios cantados. (...) por mi alma dies mill misas. (...) que resen por mi alma sesenta salmos", además de fundar "una capilla perpetua resada en la dicha eglesia de San Iohan e otra capilla perpetua cantada en el monesterio de San Françisco de la dicha mi villa de Palençuela". G. F. Fernández Suárez, La nobleza gallega..., doc. 4, págs. 294-298.

${ }^{59} \mathrm{Se}$ trataba de misas de naturaleza y periodicidad muy diversas. Desde los aniversarios o cabodanos y los treintanarios, hasta las misas cantadas o simplemente rezadas, las encargadas al amparo de una festividad concreta o aquellas que debían venir acompañadas del rezo del salterio: M. GARCíaFernández, As mulleres nos testamentos galegos..., pág. 50, nota 145. En el caso de Gregorio de Valladares (véase doc. 3) se pide, por ejemplo, "que me digan dez misas cantadas et sasenta resadas aquel dia et anos outros siguintes por mina alma et de aqueles que soo theudo. Iten mando que me digan vinte salteyros". La importancia de la celebración de los aniversarios y la percepción de las rentas a ellos asignadas originaron desde muy temprano en las instituciones eclesiásticas la elaboración de memoriales de aniversarios con el objeto de inventariar eficazmente rentas y derechos dispuestos por el orden del calendario eclesiástico, y contribuir, al fin, a una organización más eficiente de la administración señorial: véase, entre otros ejemplos del interior gallego, el caso del Memorial lucense editado por Santiago Jimenez Gómez, "O «Memorial de Aniversarios» da Catedral de Lugo como fonte para o estudio da sociedade medieval", en Jubilatio: homenaje de la Facultad de Geografía e Historia a los profesores D. Manuel Lucas Alvarez y D. Angel Rodríguez González, Santiago, Universidade, Servicio de Publicacións e Intercambio Científico, 1987, vol. 1, págs. 161227, y María José Portela Silva y José García Oro, La iglesia y la ciudad de Lugo en la Baja Edad Media: los señoríos, las instituciones, los hombres, Santiago de Compostela, Instituto Padre Sarmiento de Estudios Gallegos, 1997 (Anejo 24 de Cuadernos de Estudios Gallegos), págs. 14-15. Sobre el progresivo protagonismo de los mendicantes, véase E. Portela Silva y M. ${ }^{a}$ C. Pallares Méndez, "Muerte y sociedad...", pág. 28 e I. Beceiro Pita, "La aristocracia de Castilla...", págs. 41-45.

${ }^{60}$ F. J. Pérez Rodríguez, "Diferencias sociales más allá de la muerte...", págs. 127-142. Sumamente expresiva resulta la disposición de Gregorio de Valladares (véase doc. 3) respecto a lo que se habría de hacer tras su muerte: "mando que a o tenpo de minas honrras quebren por mi una duzea d'escudos et arrastren meus pendons pintados das armas de Meyra et Valadares et Canba, et den a meus criados et amos et amas, a cada un, sua capa de loyto": el testador aspira a organizar una escenografía en la que se mezclan cuestiones religiosas con otras ligadas estrechamente a ofrecer una imagen de poder e identidad ante la sociedad que le rodea. 
estamento eclesiástico, pero también dependientes, parientes, cofradías, simples curiosos o pobres, los cuales tenían muchas posibilidades de beneficiarse de algunos de los legados dejados especialmente para ellos ${ }^{61}$.

Por otra parte, han de examinarse los lugares de enterramiento, así como los sepulcros — moimentos, pedras o campaas chaas - encargados por los propios testadores o por sus descendientes, ya que estos elementos son sintomáticos tanto de la posición social de los individuos como de sus estrategias sociales ante la muerte, siempre con el objetivo de luchar contra el olvido y en favor de la conservación de su memoria social ${ }^{62}$. En este sentido, resultan sumamente destacadas las consideraciones realizadas en su momento por Manuel Núñez Rodríguez, así como por otros historiadores del arte medieval gallego, pues, más allá del análisis formal de los sepulcros conservados, han contribuido a clarificar la significación social de dichos monumentos ${ }^{63}$. Lo que parece observarse al respecto es la preferencia, conforme avanza la Edad Media, por los conventos

\footnotetext{
${ }^{61}$ En ocasiones, las prácticas de memoria del difunto debían suponer auténticas escenas festivas: en 1467 el comendador del Santo Sepulcro frey Juan de Loureiro ordena en su testamento que se celebre un banquete "de vaca con seu pan et con seu vinno" en el día de Todos los Santos sobre su sepultura, y lo mismo en Gomariz "sobre meu padre et mina avoa", parroquia de la que parece era natural: Isidro García Tato y Pablo S. Otero Piñeyro Maseda, "Asentamiento, desarrollo y ocaso de la Orden del Santo Sepulcro en Galicia. Un panorama general y un documento singular", Cuadernos de Estudios Gallegos, 59, núm. 125 (2012), págs. 81 y 87.

${ }^{62}$ En 1485, el mariscal Suero Gómez de Sotomayor, señor de Lantaño, pidió en su testamento "ser sepultado o meu corpo quando a Deus projer eno mosteyro de Santo Domingo da vila de Pontevedra a donde jas meo señor Padre Paio Gomez de Sottomayor e meus aboos que Santa Gloria ajan en la sepultura que ende teño feita para min": Colección Diplomática..., doc. 10, págs. 35-58. Por tanto, con anterioridad al otorgamiento de su testamento, el Mariscal ya se había preocupado por mandar hacer su sepultura, circunstancia que no debía resultar infrecuente, sino todo lo contrario.

${ }^{63}$ Manuel NúÑEz RodríGuez, La idea de inmortalidad en la escultura gallega. La imaginería funeraria del caballero, ss. XIV-XV, Ourense, Deputación Provincial de Ourense, 1985; Rocío SÁnchez Ameijeiras, "Actitudes ante la muerte en las mujeres de la nueva nobleza enriqueña: la escultura funeraria como fuente para la historia de las mentalidades", en Ángela Muñoz Fernández (ed.), Las mujeres en el cristianismo medieval. Imágenes teóricas y cauces de actuación religiosa, Madrid, Almudayna, 1989, págs. 451-461; de la misma autora "El arnés y el armamento del caballero medieval gallego (1350-1450)", Acta histórica et archaeologica mediaevalia, 10 (1989), págs. 427-436; Marta Cendón Fernández, M. ${ }^{a}$ Dolores Fraga Sampedro y M. ${ }^{a}$ Dolores Barral Rivadulla, Arte y poder en la Galicia de los Trastámara: la provincia de La Coruña, Santiago de Compostela, Tórculo, 2000; Marta Cendón Fernández, "La imagen de la mujer en el arte bajomedieval gallego", en Miguel García-Fernández, Silvia Cernadas Martínez y Aurora Ballesteros Fernández (eds.), As mulleres na historia de Galicia. Actas do I Encontro Interdisciplinar de Historia de Xénero, Santiago de Compostela, Andavira, 2012, págs. 81-100 o, entre otras, las diversas referencias contenidas en Carmen Manso Porto, Arte gótico en Galicia. Los dominicos, A Coruña, Fundación Pedro Barrié de la Maza, 1993, 2 vols., tanto en lo que concierne a los sepulcros nobiliarios como a su vinculación devocional y de promoción de las órdenes mendicantes.
} 
mendicantes o los espacios catedralicios frente a las parroquias rurales ${ }^{64}$, así como el deseo de enterrarse en los espacios interiores y en zonas lo más próximas posibles al altar. Además, se aspira a perpetuar las relaciones sociales y la vinculación familiar más allá de la muerte, de ahí que se dispongan sepulcros junto a los antepasados, los cónyuges o los descendientes ${ }^{65}$. Ahondar en estos temas recurriendo a la información recogida en los testamentos se convierte en un magnífico recurso para conocer las estrategias vitales que garantizarían la salvación individual, pero también la perpetuación de la memoria del linaje en una sociedad en la que eran necesarias estrategias muy diversas para la reproducción simbólica del grupo más allá de la muerte de uno de sus miembros.

El imaginario de la muerte y del Más Allá también ha generado una amplia producción historiográfica, insistiendo en la progresiva intensificación del miedo a la muerte en el contexto bajomedieval o en la consolidación definitiva del Tercer Lugar: el purgatorio. ¿Hasta qué punto la peste de 1348 y otras sucesivas, sumadas a la crisis económica, social y política moldean una nueva actitud hacia la muerte? ¿En qué se perciben dichos cambios? ¿Afectan a todos los grupos sociales por igual? Sin duda, los interrogantes, lejos de lugares comunes, han de propiciar respuestas serenas y abiertas a matices, las cuales sólo podrán llegar mediante el análisis de un corpus documental testamentario lo suficientemente amplio como para caracterizar con seguridad el comportamiento del grupo noble al margen de actitudes personales. De este modo, en cuanto a las posibilidades

\footnotetext{
${ }^{64}$ De todos modos, se observan excepciones a esta tendencia, como sucede en el doc. 2, en el que Teresa de Meira manda en 1470 "meu corpo sepultar na yglesia de Santa Maria de Bigo"; sin embargo, su hijo Gregorio de Valladares (véase doc. 3), estipula en 1475 que "meu corpo seer sepultado en o moesteyro de Santo Domingo da dita villa de Pontevedra, onde jaz meu padre Gonçalo de Valadares".

${ }^{65}$ M. García-Fernández, As mulleres nos testamentos galegos..., págs. 50-53. Es una lástima que adecentamientos o reformas estructurales llevadas a cabo en la época moderna en el interior de los templos hayan desnaturalizado, alterado o simplemente eliminado, los espacios de enterramiento. A este respecto los libros de fábrica parroquiales suelen ofrecer interesantes testimonios. Entre los numerosos ejemplos disponibles acerca de la remodelación de capillas familiares, merece destacarse el recogido por el P. Aureliano Pardo Villar: "de la antigua capilla de San Jorge dice Ávila y la Cueva, que estaba al costado norte de la iglesia, entre esta y la sacristía, y la demolieron los Religiosos en mis días para hacer allí otra obra; había en sus paredes a bastante altura del suelo dos magníficos sepulcros, uno al naciente y otro al lado opuesto, en que yacían el caballero Gonzalo Fernández de Toubes, y en el otro la noble señora Isabel González Vilariño, su mujer, que fabricaron y dotaron con muchas rentas dicha Capilla en los primeros años del siglo XVI. Para mayores detalles acerca de su situación, añadiremos con Boán, que se hallaba a la derecha de la puerta lateral de entrada a la iglesia": P. Aureliano Pardo Villar, OP, "El convento de Santo Domingo de Ribadavia", Boletín de la Comisión Provincial de Monumentos Históricos y Artísticos de Orense, 9, núm. 206 (septiembre-octubre 1932), pág. 415.
} 
de estudio que ofrecen los testamentos, lo mental y lo imaginario se unen a lo social, lo económico o lo cultural ${ }^{66}$.

\section{UN EJEMPLO METODOLÓGICO: TRES MANDAS TESTAMENTARIAS DE LOS VAlladARES DEL FINAL DE LA EDAD MEDIA}

Como sucede con la mayoría de los linajes históricos de la nobleza que alcanzaron protagonismo en Galicia durante la Edad Media, la casa de Valladares tampoco es ajena al vacío historiográfico acerca de su origen y primer recorrido en Galicia ${ }^{67}$. No ocurre lo mismo, sin embargo, con sus raíces portuguesas, perfectamente identificadas por José Augusto de Sottomayor-Pizarro, que dedicó varias páginas a reconstruir el inicio de la trayectoria histórica y genealógica de este linaje, cuyo solar cabe situar en la terra de Valadares, entre los márgenes del río Miño, junto a Melgaço ${ }^{68}$. El temprano protagonismo de los Valladares en la Corte alfonsina portuguesa, mantenido por alguna de sus líneas al menos hasta las últimas décadas del siglo XIII quizá como consecuencia del posicionamiento fronterizo de su solar, fue decisivo para el ascenso y consolidación de la estirpe, como parecen corroborar los Livros Velhos de Linhagens ${ }^{69}$.

Bien avanzado el siglo XIII, las líneas de los Valladares establecidas al otro lado del Miño empiezan a singularizarse en la documentación gallega, materializándose la rápida y definitiva cristalización social de este linaje en Galicia, llegando a ser uno de sus miembros más célebres Gonzalo Fernández de Va-

\footnotetext{
${ }^{66}$ Jesús Coria Colino, "El testamento como fuente de estudios sobre mentalidades (s. XIII al XV)", Miscelánea Medieval Murciana, IX (1982), págs. 193-222; M. García-FernándeZ, As mulleres nos testamentos galegos..., pág. 12.

${ }^{67}$ Felipe Castro ha dedicado una monografía a la Casa de los Valladares, si bien desde una perspectiva enfocada a la reconstrucción patrimonial y al proceso de desvinculación de bienes al fin del Antiguo Régimen; para la época medieval abunda en tópicos y reconstrucciones genealógicas desafortunadas: Felipe CASTro Pérez, A Casa de Valladares: formación e evolución do patrimonio dunha familia dominante na Pontevedra do Antigo Réxime, [Pontevedra], Deputación Provincial de Pontevedra, Servizo de Publicacións, 2004. Juan Miguel González ha publicado la transcripción de un memorial genealógico elaborado en época moderna de la Casa de Valladares custodiado en el Archivo y Hemeroteca Municipal de Vigo, abundante, como es natural, en fantasías y patrañas: Juan Miguel GonZález FernándeZ, "Genealogía de la Casa de Valladares (hasta el siglo XVII)", Boletín do Instituto de Estudios Vigueses (Glaucopis), 13 (2007), págs. 59-76.

${ }^{68}$ José Augusto de Sotto Mayor Pizarro, Linhagens Medievais Portuguesas. Genealogias e Estratégias (1279-1325), Porto, Universidade Moderna; Centro de Estudos de Genealogia, Heráldica e História da Família, 1999, vol. 2, págs. 187-205. El propio autor ya sugería la necesidad de un seguimiento de las ramas gallegas de la estirpe en la documentación del norte del Miño: id. $i b$., págs. 189-190.

${ }^{69}$ El linaje, desde muy pronto, dio origen a tres ramas secundarias que alcanzaron autonomía en el grupo parental: los Sarraças-Pias, los de Penela y los Gravel-Gabere: J. A. de Sотто Mayor Pizarro, Linhagens Medievais Portuguesas..., pág. 188.
} 
lladares, un convencido petrista que figuró entre los legitimistas refugiados en Portugal $^{70}$.

A pesar del revés Trastámara, los Valladares se documentan en Galicia firmemente consolidados al fin de la Edad Media como un grupo endogámico de peso, habitualmente emparentados con otros linajes de indudable resonancia histórica como los viejos Meira, Sotomayor, Sarraza, Deza, Montenegro, Camba o, ya al final del cuatrocientos, con los Sarmiento de Sobroso. Socialmente articulados en torno al poder arzobispal y geográficamente definidos en la zona suroccidental gallega — las terras pontevedresas de Mañó, Fragoso y otras de su entornoalcanzaron un indudable protagonismo político en el concejo de Pontevedra y, en general, al Norte del Miño ${ }^{71}$.

A partir de aquí, y más allá del marco general que se acaba de esbozar, lo que importaría saber es quiénes fueron los protagonistas de la trayectoria gallega de la estirpe, sus parentelas, y analizar su posición, prestigio y estrategias en el conjunto del concierto nobiliario gallego a lo largo de la Edad Media. Pero, como es natural, para este empeño es imprescindible contar con un amplio caudal informativo, coherente, que permita superar la poca exactitud y notoria fantasía con que se ha escrito habitualmente sobre este y otros linajes históricos gallegos $^{72}$. Sin embargo, el estudio de la conformación de este grupo familiar cuenta con dificultades añadidas derivadas del inicio de procesos judiciales ya desde la última década del siglo $\mathrm{XV}^{73}$, que motivaron la circulación de una serie

\footnotetext{
${ }^{70}$ E. Pardo de Guevara y VAldés, De linajes, parentelas y grupos de poder..., págs. 53 y 61 .

${ }^{71}$ En el célebre y noticioso Recuento de las casas antiguas del Reino de Galicia, Vasco DE APONTE califica a la casa de Valladares como de "solar bien conoçido" y "muy antiguo": Vasco de APONTE, Recuento de las casas antiguas del Reino de Galicia, Introducción y edición crítica a cargo del Equipo de Investigación "Galicia hasta el 1500" integrado por Manuel Díaz y Díaz et al., Santiago de Compostela, Consellería da Presidencia, Servicio Central de Publicacións, 1986, págs. 216, 238 y 243-244.

${ }^{72}$ Las posibilidades de estudio de este linaje galaico-portugués son amplias, ya que se pueden localizar al menos dos fondos documentales directamente relacionados con la casa: el fondo de los Marqueses de Mos-Valladares en la Sección Nobleza del Archivo Histórico Nacional y el "Archivo de los Marqueses de Valladares" custodiado en el Archivo y Hemeroteca Municipal de Vigo. A ellos se añaden los fondos documentales de los monasterios del área suroccidental gallega, a los que hay que sumar también los de Melón y los de la Catedral de Santiago, pues todos ellos son ricos en referencias sobre señalados miembros de la estirpe. Más cuidado exige el manejo de los numerosos documentos recopilados por Casto Sampedro y Folgar del Archivo del Marqués de Alcedo, custodiados en la Colección Sampedro del Museo de Pontevedra.

${ }^{73}$ Mos-Valladares, C.20, D.1 (1491-02-04 / 1491-02-05): Sentencia arbitral del bachiller Fernando González de Toledo en el pleito entre García Sarmiento, señor de Sobroso, por sí y en nombre de sus hermanos, y García Sarmiento, alcaide de la fortaleza de Altamira, y su mujer Teresa de Valladares, sobre la posesión de los bienes que quedaron a la muerte de Gonzalo de Valladares, Teresa de Meira y otros; Mos-Valladares, C.11, D.55-56 (sin fecha): Probanza mediante testigos en el pleito que sobre posesión del coto de Valladares se litiga desde 1498 entre Cristóbal Mariño
} 
de probanzas documentales ampliamente divulgadas y repetidas ${ }^{74}$. De ahí que en este punto resulte todavía más necesario el preciso análisis de la tradición documental de las mandas testamentarias de los diferentes miembros del linaje, y de reunir y examinar con detenimiento los diversos instrumentos conservados así como su cuidadosa edición; a pesar de las posibilidades de estudio que ofrecen, los documentos falsificados pueden resultar funestos para desentrañar las filiaciones y parentelas del grupo — posibles bastardías, segundos matrimonios, afillamentos - y para esclarecer el verdadero recorrido, consolidación y posición del linaje.

A modo de ejemplo metodológico, se incorporan al final de estas páginas tres mandas de otros tantos personajes pertenecientes a la estirpe de los Valladares, ilustrativas tanto por su coherencia interna como por su variedad diplomática. Se trata, el primero de ellos, de un traslado notarial del siglo XVI realizado sobre otro traslado notarial del testamento de Álvaro Fernández de Valladares (año 1397); le sigue el testamento original de Teresa de Meira en pergamino (1470) lamentablemente muy recortado en sus márgenes; y por último una copia simple de las mandas de Gregorio de Valladares, regidor de Pontevedra (1475) e hijo de aquella. En todos ellos destaca la riqueza de su contenido, tanto por las noticias patrimoniales como por las parentelas a las que se hace referencia, aunque sin olvidar lo que parece un cierto ánimo de notoriedad y prestigio en el momento de repartir generosas dádivas.

En el traslado del siglo XVI realizado por Afonso Rodríguez de Almoro, escribano de la Audiencia, sobre otro traslado de 1456 de Suero Pérez, notario público de Tuy — primer documento editado_ - la difícil interpretación de algunas de las mandas de Vasco Fernández evidencian una mala lectura del amanuense, o, acaso, un forzamiento del documento para justificar sucesiones patrimoniales ${ }^{75}$. Son también frecuentes las enmiendas, tachaduras y correcciones de las

\footnotetext{
y Gregorio Sarmiento de Valladares, como heredero de García Sarmiento. Consultado mediante Ministerio De Cultura, Portal de Archivos Españoles (PARES) [en línea], disponible en < http:// pares.mcu.es/ > [Consulta: 01/05/2013].

${ }^{74}$ Se trata, por ejemplo, de un supuesto testamento en pergamino otorgado por un Álvaro Fernández de Valladares en 1187 conservado en el Archivo del Reino de Galicia (en adelante ARG), Colección Sarmiento Valladares, 44976, Caja 168, núm. 1, ya considerado apócrifo por E. PARDO DE GuEvarA y Valdés, De linajes, parentelas y grupos de poder..., págs. 96-97; o el privilegio otorgado por el rey Fernando II de León a favor de un Gonzalo Muñoz, marido de una supuesta Aldonza Fernández de Valladares en 1159: véase F. CAstro Pérez, A Casa de Valladares..., págs. 39-41. Estos y otros documentos fueron tomados en consideración por José Espinosa Rodríguez, Tierra de Fragoso: notas para la historia de Vigo y su comarca, Vigo, Imp. Faro de Vigo, 1949, págs. 349-350.

75 "Yten mando a Fernando Alvares, meu fillo, todos quantos beens ey de la ponte de Pontevedra para acola que me pertesnesçen por herença da minna madre donna Elvira, segundo que os ela herdava de seu padre Pedro Alvares et de sua madre dona Elvira, tanben en Lantanno como en Trastamara como en Postomarcos como en Salnes como en Leyro, et en os outros lugares des la dita ponte
} 
que no da fe ninguno de los notarios otorgantes al final del documento; por el contrario, se añade al final una cláusula que sí podría encontrarse en el original ${ }^{76}$. Tampoco se puede constatar con certeza si se traslada la manda testamentaria en su integridad, al no localizarse el pergamino original. Así pues, para poder contextualizar debidamente el interés en el traslado de este testamento en 1456 y valorar su veracidad, se debe conocer muy bien el protagonismo de la solicitante del traslado, doña Teresa de Meira — testa en 1470, segundo documento- y del escudero Gonzalo de Valladares, su marido. De la misma manera, será necesario reconstruir la trayectoria vital de Vasco Fernández de Valladares y su grupo parental para poder también contextualizar debidamente el documento trasladado y disponer así de argumentos de peso para confiar o no en algunas de las noticias que contienen las mandas, además de posibilitar la identificación del torrente de personajes mencionados en él. Naturalmente, el método genealógico y prosopográfico, así como un amplio repertorio de mandas testamentarias de aquel entorno cronológico y geográfico, serán imprescindibles para este análisis crítico.

El tercer documento editado es el testamento del célebre regidor pontevedrés Gregorio de Valladares, hijo de los ya mencionados doña Teresa y Gonzalo, hombre al fin de sus días de Lope Sánchez de Moscoso, vizconde de Finisterre ${ }^{77}$. Se trata de una copia simple elaborada en los primeros decenios del siglo XVI, tomada de lo que parece fue un traslado notarial hecho a petición de su hermana Leonor de Meira por mandamiento de Lopo de Montenegro, juez ordinario de

de Pontevedra acola, unquer que os eu aja, que foron desta dita herença", y especialmente en "en todos los outros meus beens que esto que sobredito he et remanesçeren, faco (sic) meus heredeyros universaes a Vasco Fernandes et a Pero Alvares, meus fillos, et a para enpero? que mando a Vasco Fernandes el couto de Valladares con a terra de Santiago porque he mayor".

76 "Yten mando que gardandose? o que suso mando a Juan Rodrigues de Canba, que o aja con condyçion que tome as armas et o apelido de Valadares, et non no fasendo que seja destribuydo hu viren que he proveyto de minna alma".

77 "Et leixo por exsecutor de mina manda, para que façan cunplir et tenan cargo de meus fillos et do seu en quanto foren menores, et despois os aja $<\mathrm{n}>$ para si, a o viscond $<\mathrm{e}>$ de Finsterra, meu sennor". El título de vizconde de Finisterre fue empleado por Lope Sánchez de Moscoso desde su posible concesión por el rey Enrique IV en 1473, hasta que los Reyes Católicos le conceden el título de "conde de Altamira" alrededor de mayo de 1475. Véase un claro y detallado estudio en Ana María Framiñán SANTAS, "O título vizcondal de Fisterra no contexto da creación de títulos en Galiza na Idade Media", Boletín de Estudios de Genealogía, Heráldica y Nobiliaria de Galicia, 3 (2004), págs. 430-431. A partir de las informaciones suministradas por Vasco de Aponte parece interpretarse que el Conde de Camiña cortó la cabeza a Gregorio de Valladares junto a Tristán de Montenegro, ya que dice "a ambos procuró con todos sus pensamientos de les cortar las cabeças, y púsolo por obra"; sin embargo, el mismo cronista pone sobre la pista del dilatado pragmatismo de Gregorio de Valladares, al afirmar también que pertenecía a la casa de Álvaro Páez de Sotomayor, con cinco o seis escuderos, y cien vasallos, o que ayudó en torno a 1470 en el cerco de Altamira al arzobispo Fonseca, el patriarca, en su lucha contra Lope Sánchez de Moscoso, el futuro vizconde de Finisterre: V. de Aponte, Recuento de las casas antiguas..., págs. 183, 216, 238, 243-244. 
Pontevedra $^{78}$. De nuevo no puede precisarse con certeza si el conjunto de las mandas en él contenidas es veraz o si hubo diligencia por parte del amanuense al hacer la lectura y transcripción del documento original. Lo que sí llama especial atención en esta copia es la alusión a un supuesto mioradigo que correspondería a Pedro Vázquez, hijo de Gregorio de Valladares, pero tanto la enrevesada redacción del documento como lo que parece tratarse de unas correcciones hechas $a$ posteriori dificulta la interpretación de quién sucedería en la casa de Valadares y en el couto de Sajamonde, mencionados a continuación ${ }^{79}$. De nuevo se hace aquí imprescindible acometer una confrontación con otros documentos y elaborar un minucioso análisis prosopográfico del personaje y de su grupo parental para poder decidir sobre la veracidad de la información que contiene.

$$
* * *
$$

Todo el conjunto de noticias que se pueden obtener a partir del vaciado integral de los testamentos, en particular de los no originales, en el ámbito de la historia social de la nobleza, se debe completar y contrastar con los ofrecidos por un amplio repertorio de documentos afines, en ocasiones derivados de aquellos; es el caso de los inventarios - magnífica fuente para intuir con mayor detalle los niveles de riqueza, así como la vida privada y cotidiana de los nobles-, las partijas de bienes, las cartas de dote o los pleitos patrimoniales, a los que se suman otros de naturaleza diferente, como pueden ser los foros, las permutas, las avenencias, la concesión de privilegios y las vinculaciones o fundaciones de mayorazgo. La suma y análisis de sus noticias cristalizará en la clarificación de las estrategias de ascenso, descenso o ingreso en el grupo, los criterios de jerarquización o, incluso, en los procesos de reproducción, tanto biológica — basada

\footnotetext{
${ }^{78}$ En todo caso, esta copia simple es anterior a un traslado notarial de Gonzalo de Reguera, escribano del rey y del cabildo de Santiago, realizado en 1576 a pedimento del canónigo Diego Suárez de Tangil para la Real Audiencia y Chancillería de Valladolid, custodiado en ARG, Colección Sarmiento Valladares, 44976, Caja 168, núm. 6.

79 "Iten mando que partan as cousas propias con meus yrmaoos segundo que as partiron Pedro Albares de Valadares et Vasco Fernandes de Valadares, et das outras cousas que a meu cabo perteesçe faço meus herdeyros a Pedro Vaasques de Valadares, meu fillo, et a? Teresa de Meyra, sua yrmaan, et asimismo de todos los outros meus beens mobles et rayzes que eu teno, minas mandas conplidas, os quaes beens mando que ajan et herden en esta guisa: que por quanto a o dito Pedro Vasques, meu fillo, perteesçe o mioradigo ( $\mathrm{sic}$ ), mando que leixe a dita sua yrmaa o couto de Meyra et a mayor parte dos casares propios que me acaesçeren dos casares de Canba et Pias et Mouriscasdos et Salvaterra, et as colleytas dos benefiçios que a min perteesçen en Torono, salvo das freiguesias que a el perteesçen, que son estas, os feuldos da yglesia de Santiago. S Iten lle mando mays que aja et herde a casa de Valadares, a melloro en o meu couto de Sajamonde con suas vinas, casas et herdades et con todas suas perteenças para que ninguna non posa partir con el".
} 
en la existencia de unas determinadas estructuras de parentesco-como social, económica, política y cultural, manifestadas en los modos de vida o actitudes ante la muerte.

En este empeño se precisa una sólida y amplia base heurística que permita lecturas y análisis minuciosos y exhaustivos fundamentados en el rigor metodológico y la crítica de fuentes que los simples vaciados, cuantificaciones o anotaciones documentales imposibilitan, de forma que se logre alcanzar la veracidad o intención del caudal informativo. Por esta razón, la conformación de un vasto corpus o repertorio testamentario de la heterogénea nobleza medieval gallega debe constituir un primer paso irrenunciable, evitándose así la notable dependencia de antiguas y meritorias ediciones documentales cuyas transcripciones no responden ya, en general, a los criterios, posibilidades y exigencias de la historiografía actual, y en particular, en lo referido a la historia social de la nobleza. En esta línea, tanto proyectos de investigación básica ${ }^{80}$ como iniciativas individuales $^{81}$ deben dar a conocer nuevos instrumentos y metodologías de análisis, posibilitando la reunión de un conjunto completo, coherente, crítico y ordenado de piezas documentales susceptibles de ser analizadas desde diferentes tendencias o ámbitos de especialización.

Las cuestiones apenas enunciadas en estas páginas atañen, en síntesis, a lo más fundamental del asunto planteado: avanzar en el conocimiento de los linajes y las redes parentales de la nobleza medieval gallega y su proyección o ascenso en los inicios de la Modernidad, a partir principalmente de las reconstrucciones genealógicas y el análisis prosopográfico. Pero en cualquier caso, las líneas de trabajo y las consideraciones metodológicas avanzadas aquí no suponen un ago-

\footnotetext{
${ }^{80}$ Entre los que se puede mencionar "Mulleres con poder ao final da Idade Media. O testamento, a morte e a memoria", realizado en el Instituto de Estudios Gallegos "Padre Sarmiento" bajo la dirección del Dr. Eduardo Pardo de Guevara y Valdés y financiado por la Secretaría Xeral de Igualdade de la Xunta de Galicia. Este tipo de iniciativas también se están llevando a cabo en otros países del entorno, dando lugar a publicaciones de gran interés como la coordinada por Maria do Rosário Barbosa Morujão (coord.), Testamenti Ecclesiae Portugaliae (1071-1325), Lisboa, Centro de Estudos de História Religiosa-Universidade Católica Portuguesa, 2010.

${ }^{81}$ No existen en Galicia monografías dedicadas exclusivamente a los testamentos y documentos afines, caso de codicilos, inventarios, mandas, fundaciones de aniversarios y mejoras, partijas de bienes o disposiciones mortis causa en general, por citar algunos ejemplos. Sin embargo, no sucede lo mismo en otros ámbitos geográficos: a modo de ejemplo se puede señalar en el espacio aragonés la existencia de ediciones de libros testamentarios o de colecciones documentales como la de Ana del CAmpo Gutiérrez, El Libro de Testamentos de 1384-1407 del notario Vicente de Rodilla. Una introducción a los documentos medievales de últimas voluntades de Zaragoza, Zaragoza, Institución "Fernando el Católico", 2011. En esta línea, pero destacando ya la utilidad del análisis de los testamentos como fuente para la historia de las mujeres y de las relaciones de género, Maria Teresa Brolis y Andrea Zonca, Testamenti di donne a Bergamo nel medioevo, Bergamo, Fondazione Mia, 2012.
} 
tamiento del tema; muy al contrario, los estudios de base, las comparaciones con otras áreas geográficas o los análisis abordados desde otras tendencias historiográficas enriquecerán las temáticas, los métodos y los enfoques. Naturalmente, los estudios comparativos deberán tener en cuenta las jerarquías existentes dentro del grupo noble, y en consecuencia deberán valorar también las noticias documentales atendiendo al contexto social y económico de cada una de las noblezas medievales, a su cronología y a su posición en el concierto nobiliario de un determinado espacio señorial.

\section{EDICIÓN DOCUMENTAL ${ }^{82}$}

\section{1}

1456, abril, 9.- Tuy

Traslado autorizado ante Pedro Marraón, alcalde de Tuy, a petición de doña Teresa de Meira, viuda de Gonzalo de Valladares, escudero, otorgado ante Suero Pérez, notario público de Tuy, de las mandas testamentarias de Álvaro Fernández de Valladares (1397, septiembre, 20.- Sajamonde) y de una declaración de diversos clérigos sobre el pago de servicios a Vasco Fernández de Valladares (1401, agosto, 20.- Redondela).

LA CORUÑA, ARG, Colección Sarmiento Valladares, 44976, Caja 168, núm. 2, papel, traslado notarial del siglo XVI de Afonso Rodríguez de Almoro, escribano de la Audiencia, gallego, letra procesal; 44976, Caja 168, núm. 2, papel, copia simple del siglo XVII, letra bastardilla española.

Observaciones: Se transcriben las cláusulas del traslado en letra de menor tamaño. A pesar de que el traslado del traslado no está fechado, el tipo de letra parece evidenciar que se realizó en el siglo XVI. La copia simple tiene numerosas inexactitudes y errores de transcripción.

Yn Dey nomine, amen. Anno del nasçimiento de nuestro Sennor I Ihesu Christo de mill et quatroçientos et çincoenta et seys annos, I nueve dias do mes de abril. Sabean todos quantos I este publico ynistormiento (sic) vieren que ante Pedro Marraon, I alcalde da çibdad de Tuy per noso sennor el rey, sendo I en abdiençia publica, oyndo pleytos et causas et negoçios en o seu I lugar acostunbrados, en presençia de min o notario publico I et $\mathrm{t}^{\mathrm{o}} \mathrm{s}$. a yuso escrytos, paresçio donna Theresa de Meyra, I muller de Gonçalvo de Valla-

\footnotetext{
${ }^{82}$ Se siguen los criterios de transcripción expresados en la edición del testamento de frey Juan de Loureiro: I. García Tato y P. S. Otero Piñeyro Maseda, "Asentamiento, desarrollo y ocaso...", pág. 85. Por otro lado, los autores agradecen a Ignacio Pérez-Blanco Pernas, marqués de Valladares, las primeras noticias de la existencia en el ARG de los documentos que ahora se publican.
} 
dares, es [cudeyro que fue], que Deus I aja, et presento et ler fizo a min o dito alcalde huna I manda escrita en pregamino (sic) de cuero fyrmada I dos nomes de Juan Fernandes, et de Juan Fidelis, et de Juan Yalnes, clerigo de Sajamonde, et Lourenço Yannes, et Juan Yalnes, clerigo de Çedeyra, et Fernando Soares, et Martin Rapela, I et Domingo Duran, sygnada et su escrita co nome l et sygnal de Estevan Soares, clerigo do obispado de I Tuy, notario publico apostolico; et presentou mays logo ante I o dito alcalde a o notario on (sic) ynistormiento escrito en palpel, sygnado et so escrito do nome et sygnal I de Estevo Mialla, notario publico jurado de Redondela I et de terra de Manoo, saanes et yntegros, non rasos nen I vyçiados nin cancelados nin en alguna parte deles de sy I sospeytosos et mays de todo viçio et sospençion causanltes, segundo por eles primera pares (tachado) façia <et> paresçia. Dos I quaes dita manda et ynstormiento segundo foron presenltados un en pos de outros, os tenores deles de verbo I a verbo son estes que se syguen:

Yn Dei domini, amen. I Anno do nasçemiento de nuestro Senor Yhesu Christo de mill et trellzientos et noventa et siete annos. Sabean quantos esta manlda et testamiento vieren que eu Alvaro Fernandes de Vallladares, estando con saude con todo meu syso l et entendimiento qual me $<$ Deus $>$ quis dar, faço minna manda et testalmiento et minna postromeyra voontade et depoemiento de I meus bens en esta maneyra que se sygue: yten mando logo I primeyramente a minna alma a Deus Padre I que a conprou et redemeu por lo seu corpo et sanlgre preçioso, et rogo a Vyrgen Santa Maria, sua maldre, con toda a corte çelistial, que queyra resar por I ela a o meu Sennor Ihesu Christo. Yten mando que quando I aconteçer de me yr deste mundo, que sepultar o meu I corpo dentro en o mosteyro de Santa Maria de Mellon, dentro I do coro da yglesia. Yten mando conmigo a o dito I mosteyro et abad et convento del tresentos maravedis et una I [pitanza...] venco? que perdoe a min l et a meus avos o que ouvemos do dito mosteyro. Yten I mando a Fernando Alvares, meu fillo, todos quantos beens I ey de la ponte de Pontevedra para acola que me I pertesnesçen por herença da minna madre donna I Elvira, segundo que os ela herdava de seu padre I Pedro Alvares et de sua madre dona Elvira, tanlben en Lantanno como en Trastamara como en Postolmarcos como en Salnes como en Leyro, et en os outros I lugares des la dita ponte de Pontevedra acola, unlquer que os eu aja, que foron desta dita herença. Outrosy lle I mando a o dito Fernando Alvares o casal de Veemill que ten I de min Fernando Cao por tres mill maravedis se llo Fernando Cao I quiser leyxar et tornar seus dineyros. Yten mando a todos $\|$ aqueles que ouve dado sen seu graado dos que non I conosco nin sey quaes son, por las suas almas, quilnentos maravedis, et se distribuyan ou ( sic) <que> entenderen os melus conpridores que he (un tachado) mays conprideyro. Yten man $\backslash d o /{ }^{83}$ I a o mosteyro de San Pedro d'Angoares et a $\mathrm{o}$ avade et convenlto del tresentos maravedis, et eles que perdoen a meus avoos

\footnotetext{
${ }^{83}$ Se escribió "mays" y se corrigió por encima "mando".
} 
I et a min o que ouvemos do dito seu mosteyro. Yten manldo a o mosteyro de Vodinno et a o prior et convento del trelsentos maravedis, que (tachado) et eles que a meu padre et a meus I avoos et a min o que do dito mosteyro ouvemos, que lle perdoen. I Yten mando a o mosteyro de Santa Maria d'Oya et o avade et I convento del tresentos maravedis, et ellos que perdoen a meus $\mid$ avoos et a min $<0>$ que ouvemos do dito seu mosteyro et a meu I padre. Yten ma $<$ n $>$ do todo aquelo que acharen por voa I verdade \que yo devo/ que se pague. Yten $m a<n>$ do a todos os de Garlgamala et Savagaas et os de Junqueyras, a quen I eu errey, que le façan delo corrigimiento. En todos los I outros meus beens que esto que sobredito he et remanesçelren, faco ( $\mathrm{sic}$ ) meus heredeyros universaes a Vasco Fernandes I et a Pero Alvares, meus fillos, et a para enpero ${ }^{84}$ I que mando a Vasco Fernandes el couto de Valladares con a terra I de Santiago porque he mayor. Yten mando que os folros que eu tenno por vozes que os partan de per meo o al I que façan entresy pesoeyro. Yten mando a os ditos I Vasco Fernandes et Pedro Alvares, meus fillos, que enbien por I meu padre et por meu hermano a corte que os fagan sote|rrar $(\mathrm{sic})^{85}$ et que os sepulten en o mosteyro de Mellon. Yten manldo que morrendo os ditos Vasco Fernandes et Pedro cada un deles I sen fillo ou filla legitymos, que os deys (tachado) ditos bens II que se tornen a o outro, et morrendo o outro tanben sen fillo I ou filla legitymos, que se tornen os ditos bens a Juan Rodrigues I de Canba, fillo de minna hermana Sancha Rodrigues, y molrrendo o dito Juan Rodrigues sen fillo ou filla legitima, que os I ditos bens que os destribuyan os ditos meus conpridores con I aqueles a que des ( sic) deyxaren cargo se non foren bibos, et I façan des capelas quaes vieren que se poden servir et I manter por ellos. Et faço mas conpridores desta minna I manda a Juan Nunes, tesorero de Tuy, et a Lopo Rodrigues, I arçidiano de Montes en esa dita s (tachado) yglesia, et rogolles I que a cunpran por lo meu et seu sen dapno, et mandolle I por seu tras (tachado) afan que tomare tresentos maravedis a cada un. I Yten mando, quero et outorgo que se allares? testamiento ou couldiçillo \fezo ou/ ${ }^{86}$ teno feytos antes, que non vallan et mas (tachado) Ique aqui os/ revoco I et hey por revocadas, et otorgo que non vallan salvo esta. I Et quero et outorgo que valla como minna manda et testalmiento; se non valuer $\backslash$ como/ mina ma $<\mathrm{n}>$ da et testamiento, que valla I como coudiçillo, et se non valer como coudiçillo, I que valla como minna postromeyra vontade.

Feyta en I Sajamonde, a veyente (sic) dias do mes de setenbre.

\footnotetext{
${ }_{84}$ Transcripción muy dudosa porque parece que está tachada en algunas partes de las palabras.

${ }^{85}$ Enmendado posteriormente y añadiendo "soltre?".

${ }^{86}$ Añadido posterior.
} 
$\mathrm{T}^{\mathrm{o}} \mathrm{s}$. que I presentes foron para esto espiçialmente chamados et rolgados: Juan Fernandes, Juanes Fidelis et Ju<an> Anes, clerigo de Sajamonde, Lourenço I Yannes, clerigo de Çedeyra, Fernando Soares, Martin Rapela, Domingo I Duran.

Yten mando que gardandose? o que suso mando a Juan Roldrigues de Canba, que o aja con condyçion que tome as armas et I o apelido de Valadares, et non no fasendo que seja destribuyldo hu viren que he proveyto de minna alma.

Et eu, Estevo Soares, I clerigo do obispado de Tuy, publico autoritate apostolica, que a esto que susoldicho he con las dichas testemoyas ( sic) que presentes fueron, para I esto espeçialmente chamados et rogados, et esta manda a I rogo do dito Alvaro Fernandes con minna mano escrevi, et en ella I mi nonbre et sennal fize en testimonio de verdade. II

Anno del nasçimiento de noso Sennor Ihesu Christo de mill et quatroçentos I et un annos, vinte dias de agosto, en presença de min, Estebo Meallla, escrivano publico jurado de Redondela et de tyerra de Mannoo et de sus I terminos por lo sennor arçobispo da yglesia de Santyago, et das testylmoyas (sic) que adelante son escritas, en Redondela, en a Ria da Ponte?, I estando ay Martinno Carreyro, clerigo de Vilardenfesta, et Afonso I Gonçales, clerigo que fue de Nespereyra, et Martin Yanes, clerigo de I Santystebo de Negros, et Ruy Muniz, abad de Riboredo, et I Gonçalo Estebes, clerigo de Samamede de Maçeyro, et Juan de Syllvoso, clerigo d'Amoeda, et Fernand Lourenço, clerigo de San Lourenço (tachado) Ityago de Borben, clerigo (enmendado), y Basco Fernandes de Baladares. Et dyço a os I ditos clerigos a quien deran $\mathrm{o}<\mathrm{s}>$ serviçios destos anos pasados; et eles I dyseron todos que ho deran a Lourenço Rodrigues et a Gonçalvo Lopes, mayorldomos de vos, dito Vasco Fernandes, en voso nome. Et desto en como I pasou o dito Vasco Fernandes pedeu a min, dito notario, testymunio I para garda de seu derecho, os quales clerigos hafyrmaron I que deran estes dereytos dos serviçios a o dito Lorenço I Rodrigues et a o dito Gonçalvo Lopes por juramento dos Santos Avangeos. I

Testymunnas que foron presentes: Fernan Taravela, I et Juan Porra, et Juan Yanes, clerigo de Saxamonde.

Et heu, Estevo I Mialla, notario publico jurado de Redondela et de tyerra de I Mannoo, que a esto presente fuy con as ditas testymuas I et ho fyrmey, puje aqui meu nonbre et synal en testylmonio de verdad, que tal he.

Antre (tachado) $\backslash \mathrm{La}$ qual/ dita manda et ynstrulmento asy presentados et leydos a dita donna Tareisa de Meyra, por sy et I en seu nome et de Grigorio de Valadares, seu fillo, et do dito I Gonçalo de Valadares, seu marido, que foi, que tinna en en (sic) seu poder I pequeno et menor de ydade, do qual diso que era sua tutora et guardaldora del et de seus bie- 
nes, dyso que el (tachado) <e>la se entendia aprobeytar das ditas I manda et ynstrumentos se pode (tachado) et de cada uno deles, asy en juylzio como fora del en este reygno et provinçia de Castela I et de Leon, et en a corte de Roma, et de noso sennor el rey, et en II houtras partes, et que se temia et reçelava que por venltura a dita manda et ynstrumento se poderia perder I por furto, força, roubo, fogo, agoa, valleçe ( sic), ou por I outro fortytuito caso, por ende que ella por sy et en nome do I dito Gregorio de Valadares, seu fylloo, en os mellores moldo, via, cabsa, forma, que podia et devia de dereyto, I pedia et pedeu a o dito alcalde que mandase a mi, notario publico I a yuso escripto, que dos ditos manda $<$ et> ynstrumento publicos et de cada I uno deles sacase, escripve (tachado) lescrivie/ se, ou mandase sacar et scripvir I suas verdadeyras copias ou trasuntos concordados I con seus propios origynaes, en publica et abtentyca forma, I sygnados et subescriptos de meu sygno o suscriçion, I a os quales et cada uno deles dese sua abtoridade I ordinaria et ynterposese seu decreto para que vallesen et felzesen $f e$ (tachado) conplida fee, en juyzio et fora del, asy como I a seus propios originales. Et o dito alcalde tomou tomou (sic) I os ditos manda et ynstrumento en suas manos et as I leu, exsaminou et deligentemente catou et mostrou en a dita I publica abdiençia a os escripvaas et notarios publicos, et $a b$ (tach $a$ do) a $<0>$ utras personas (tachado) abtentylcas personas que eran presentes. Et vistos et exsaminados por lo dito $\mid$ alcalde et $<$ aqu $>$ eles os que eran presentes, dyso que por quanto os ditos manda I et ynstrumento lle paresçia ser verdaderos, sanos et I integros, no rasos, no cançellados nen veçyados, nen en allguna parte de sy suspeytosos segundo por eles paresçia, por I ende que mandava et mandou a mi, notario publico a yuso escripto, que I dos ditos manda et ynstrumento sacase ou escryviese ou I mandase sacar et escryvir verdadeyra copia ou trasunto conlcordado ou colaçionado con sus propios origynales, quantos I lle nesçesarios fosen, et os sygnase et subscripviese de I meu sygno et subcriçios, quaes ditos copia ou trasunto dos ditos I manda et ynstrumento origynaes sacados, escriptos, conlcordados et colaçionados, sygnados (un tachado) et subscriptos, I sygnado como dito hes de mi, o dito notario publico, que o dito alcalde lle II dava et dio a cada un deles su abtoridad ordinaria, et ynlterponia et ynterpuso a ellos su derecho (sic) porque valiesen et I fiziesen conplidamente fe en juyzio et fuera del, asy como I los sus propyos originales. Et a dita donna Theresa I de Meyra, por sy et en el dicho nonbre, pedio a mi, o dito notario I publico, o publico ynstrumento o ynstrumentos para guarda de I su derecho, sua et do dito seu fillo; et a los presentes rogo que fuesen I delo ts ${ }^{\circ}$.

Et esto foy en a dita çibdad de Tuy, en a dita abd[iençia] I publica, anno, dia et mes susodichos.

Presentes a ello por $\mathbf{t}^{\circ}$ s.: Gonçalvo de I Verga, alfayate, et Vasco Pardo, notario da dita çibdad, et Fernando I Tarqueyro, andel? dela, veçinos da dita çibdad, et Ruy Gomes de I Martin, et fijo de Suero Gomes de Martin, escudeyro que fue, que Dios aya, I criado do sennor Alvaro de Sotomayor.

Et yo, Suero Peres, I notario publico jurado da dita çibdad <et> obispado de Tuy por el I obispo et cabildo de la yglesia de Tuy, a todas las cosas I susodichas et a cada una dellas en uno con los dichos I [ts...] I copyas o trasunto por mandado do dito alcalde [et a] I petiçion da dita donna Theresa de Meyra, por otro [...] I lo fize escrevir, et por ende mi sygno acostunbrado I lo sygne, en testimonio de verdad, rogado et requerido. I 
Fue conçertado este traslado por min, Afonso Rodriguez de Almoro, I escrivano desta abdiençia. I

(Autógrafo) Afonso Rodrigues de I Almoro, notario.

\section{2}

1470, mayo, 2.

Testamento de Teresa de Meira por el que manda enterrarse en la iglesia de Santa María de Vigo y nombra universales herederos a sus hijos Gregorio de Valladares, Leonor de Meira y Diego Suárez.

LA CORUÑA, ARG, Colección Sarmiento Valladares, 44976, Caja 168, núm. 3, perg., orig., gallego, letra precortesana, $235 \times 345 \mathrm{~mm}$., muy recortado en sus márgenes derecho e izquierdo.

[En o nome de Deus, amen. Anno do nasçemento de noso Sennor Ihesu Christo de mi] 11 et catroçentos et seteenta annos, dous dias do mes de mayo. Eu, Tereysa de Meyra, jazendo doente do meu corp[o...] I [... de] 1 me de Deus tebo por ben de me dar, empero con todo meu siso et emtendemento, faço et ordeno minna manda et meu t[estamento...] I [...] a maneyra seginte. $\int$ Mando a minna alma a Deus Padre poderoso que son pe $<$ r $>$ sonas tres Padre, et Fillo et Espiritu Santo, a qual el [...] । [...] seu sangre justu (sic) et preçioso. $\int$ Rogo a Virgen Santa Maria con todollos santos et santas da gloria do Parayso que seja minna aboga[da...] I [...] a ho dia do juyzo. $\int$ Mando meu corpo sepultar na yglesia de Santa Maria de Bigo. $\int$ Mando polos meus bens coreen[ta misas...] I [...] anno a parte com cura de Santa Maria de Vigo, et que o clerigo que della for que me diga huna misa cantada con huun $r[$ esponso...] I [...] mon en o dia que meu corpo for sepultado, et que meus erderos ofreçan a dita misa cada anno que se ella diser para et $v[\ldots] \mid[\ldots]$ misas no dia de minna sepultura et dez salteyros, et se se todos non poderen dizer em huun dia, que se diagan (sic) todos [...] | [...] missas que se non diseren no primeyro dia. $\int$ Aqui declaro minnas devedas que devo de que soo acordado: $\int$ devo a Pedro d[...] | [...] entos maravedis vellos, et el ten de min huna abotoadura que e de Maria Veyra; mando que quiten a dita abotoadura et a dian a dita [Maria Veyra...] । [... Afonso] de Nispereira o alugeyro do fumeyro que me alugolu/ por $\mathrm{d}<\mathrm{o}>\mathrm{us}$ annos cada anno por saseenta maravedis, et el ten de min car[ta...] । [...] et duas de çenteo, et mays o apostamento que apostey o dito fumeyro. $\int$ Devo mays a ho dito Afonso de Nespereyra huna duzea $[\ldots] \mid[\ldots]$ o que el diser por sua verdade, os quaes el me dou para çerto çenteo que me el mercara. $\int$ Devo a Maria Rodrigues çento et sateenta maravedis [...] 
I [...] ouro et hun coral empegado, em prata. $\int$ Devo a Maria Çestinan coreenta maravedis, et ela ten de min çertas prendas de prata [...] [ [..] os de prata, et mays huun relicario de prata. $\int$ Devo a Costança Meendez viinte maravedis, et $<$ e>la ten por eles huna garg[antilla...] I [...] catro doas de prata, as quaes doas som de Miçia, minna neta, mando que llas dian s (tachado). $\int$ Devo mays a dita Costança Meend[ez...] I [...] huna çinta de prata et de tegillon verde. $\int$ Devo a Juan do Barreyro quinentos maravedis, et el ten de min huna taça de prata que ten huun mar[co...] I [...] mays huun rayal, mando que saquen a dita taça et a dian a muller que foy d'Afonso de Muoas de Redondella. $\int$ Demanden [...] I [...]s çertas prendas de prata que eu puge a sua madre Tareyja Peres, muller que foy de Pedro Martiz, carneçeiro, as d[...] I [...] de prata que ten huun cruçifijo et dous torneses ${ }^{87}$, huna em presadura tres botoons de prata sobredourados. $\int$ Ten de $\min [\ldots] \mid[\ldots]$ de prata que ten outro cruçifixo, et eu devolle sobre el o que el diser por sua verdade. $\int$ Ten de min Ines Gonçales $\mathrm{m}[\ldots] \mid[\ldots]$ prendas de prata, as quaes ela dirá por sua verdade, et non lle devo sobre elas nada. $\int$ Devo a Garçia, prateyro de Pont[evedra...] I [...] et pesaban os ditos bincos ${ }^{88}$ o que el diser por sua verdade; et el ten de min huun relicareo de $\mathrm{pra}<\mathrm{ta}>$ que ten dentro huun cruçi[fixo...] । [...] Santa Maria, toda de marfil, mando que lle pagen os ditos vincols/ et demandenlle o relicareo. $\int$ Ten de min a muller que foy de $[\ldots] \mid[\ldots]$ de prata dourada, que montaria tres marcos de pra $<\operatorname{ta}>$ ontre ouro et feitura, et eu non lle devo nada sobre ela. $\int$ Devo [...] I [...] Chamorro, fustan ${ }^{89}$ para huun gibom, mando que lle pagen por el o que el diser por sua verdade; et el ten de min polo dito fu[stan...] I [...] em garda a Maria Gonçalves, ama que foy do dito Fernan Gonçalez, huna dobra d'ouro, et moytas vezes lla pidi et non $[\ldots]$ । [...]s della a ho dito Fernan Gonçalvez mando que lla demandem, poys queren os ditos beens que el ben sabia parte da dita $\mathrm{d}[\ldots] \mid[\ldots]$ muller que foy de Roy de Lugu (sic) çerta deveda sobre huna abotoadura de prata dourada, a grandiça (sic) mando que lla pa[...] | [...] et aja dela a dita abutuadura. $\int$ Devo a Roy Gonçalves, meu criado, huun florin d'ouro. $\int$ Mando a meus fillos [...] | [...] dito Roy Gonçalves tres teeygas de pan para sua manteença na minna quintaa de Felgeyras, et que o dito pan seja terça [...] । [...] et esto seja em toda sua bida porque lle soo moyto obrigado por moyto serviço que me a feyto. $\int$ Devo [...] । [...] Freygeendo dozentos et çincoeenta maravedis. $\int$ Devo $<a>$ Afonso Mannoz çertos maravidis de vinno, non sey quantos son, pagenlle [...] | [...] na verdade. $\int$ Devo a Junça, (un tachado) judio, morador en Monçon, dozentos maravedis, que el ten de min huna abotuadura, a grand [...] । [...] botoons. $\int$ Devo a Garçia de Valtar çerto pano que lle tomey, o qual el dirá por sua verdade. $\int$ Devo <a>

\footnotetext{
${ }^{87}$ Moneda de Tours.

${ }^{88}$ Vinco: pendientes que usan las mujeres formados por un aro de plata.

${ }^{89}$ Tejido.
} 
Afonso Peres, alumin[...] I [...] os maravedis que my el emprestou, que lle pagen o que el diser por sua verdade. $\int$ Ten de min Gomez, carpenteyro, morador em $\mathrm{P}[\ldots] \mid[\ldots]$ sangre? que e d $\mathrm{l}$ o/uro, a qual sortella le foy posta por huun atoude (sic) que el fezo, em que lançaron <a> Gonçal de Valadares de man[...] I [...] ]o deven et façao por sua verdade. $\int$ Devo a Lourenço de Nespereyra çertos maravedis de çerto sal que me fiou a Lourenço Gomez, mando que o [...] I [...] Agude, morador en Monçon, çen maravedis que me emprestou. $\int$ Demanden Afonso do Porto huna atado $^{90}$ de prata por (tachado) que puje em pren[...] I [...] çerto ferro, et pageylle o dito ferro, et non devo nada sobre o dito atado. $\int$ Tenno huna verea con Alvaro Afonso, juyz de Vig[...] I [...] stou sobre çertos fiadores, et el prendeu a hos fiadores et trouxome çerto triigo de Felgeyras que seria çento et viinte çe[...] । [...] sintada mando que façan con el conta, et quem dever que page. $\int$ Mando que dian \a Maria/ Alvares duas teygas de triigo, et lle façan [...] | [...a]lguun vier, que diga que lle eu soo obligado en agl (tachado) alguna cousa, et o fezer verdade, mando que llo pagen. $\int \mathrm{M}[\ldots]$ I [... Sam] Domingo de Pontevedra çen maravedis, et que os frades me digan duas misas por minna alma et dous responsos [...] | [...] de Pontevedra outros çen maravedis, et que me digan outras duas misas. $\int$ Mando que dian a frey Rodrigo d'Utreira de Santo [...] | [...] sabaas et vinte maravedis por minna alma, et pidolle que me perdoe por amor de Deus. $\int$ Mando a Sam Domingo de $\mathrm{Tu}[\mathrm{y} . .$.$] । [...] a misa$ cantada por min et por minna geeraçon. $\int$ Mando que dian cada anno polos meus beens de Meira viinte [...] | [...] a parte concura, et o clerigo que della for diga cada anno duas misas por minna geeraçon et por min. $\int$ Mando a $[\ldots] \mid[\ldots]$ nan da Rotea. $\int$ Mando a confraria de Santa Maria Madalena de Vigo çen maravedis, et a confraria me omrre. $\int \mathrm{Man}<\mathrm{do}>\mathrm{m}[\ldots] \mid[\ldots]$ da villa de Salvaterra con as erdades que jazen arredor dela a meu fillo Grigorio de Valadares por quanto foron $[\ldots] \|^{91}$ [... Di]ego Suarez, meu neto, a vinna da Varçiela, como jaze; mando $<$ con $>$ seu resio ${ }^{92}$ et con o seu lagar, et mays as erda [des...] I [...] mando a leyra da erdade que traje Juan Esteves, varqueiro. $\int$ Mando a Lionor de Meyra, minna filla, as vinnas [...] I [...]van que jaz na veyga de Freygendo con a erdade que jaz no caminno sobre la vinna da Varzela que e a metade de $d$ [...] I [...] se quiseren huna vinna que me trage Juan Rodrigues de Deça por força, et eu a tenno por sentenca et non me vale nada [...] | [...] de Valadares a terça parte do casal de Quiteella porque foy conprada para el polos seus dineyros que ouve de sua [...] I [...]s clerigo, meu criado, çen maravedis porque lle son obligado delles, et em outras cousas. $\int$ Mando a o clerigo que me tever [de la mao a o momento do meu falesçemento] I [...] $\int$ Leyxo por meus erdeiros a meus fillos Gregorio, Lionor

\footnotetext{
${ }_{90} \mathrm{P}$. una caja pequeña.

91 En el reverso escrito a la inversa.

92 Lo que está alrededor.
} 
et Diego Suarez huniversas em todos meus b[eens...] I [...]z, et les mando so pena de minna beyçon que cunpra toda esta minna manda, et dian lugar a meus conpridores que a cunpran [...] | [...] dita manda em juyzo et fora del por canto asi e minna derradeira vontade. $\int$ Leyxo por conpridores desta minna [manda et testamento...] I [...] et a meus fillos Gregorio de Valadares et a Diego Suares.

$\mathrm{T}^{\mathrm{a}} \mathrm{s}$. que foron presentes: Juan de Nespereyra et Gonçal P[...] । [...] Vidal, moradores na villa de Vigo, et outros.

Et eu, Gomez Fernandes, clerigo et notario apostolico que con as sobreditas $\mathrm{t}^{\mathrm{a}} \mathrm{s}$. chamado et $\mathrm{r}[\mathrm{ogado} . .$.$] I foy a hordenança et feytura desta manda, et em$ minna presença foi outorg[ada...] I minna maao, et ven et fielmente escriby em esta carta de pulgaminno da [...] I et aquy puje meu nome et sinal acustumado em de verda[de que tal he].

(SIGNO: al pie): Gomecius Ferdinandi I [nota]rius apostolicus.

(Autógrafo rubricado) Gom[ez Fernandez] I notario a[postolico].

(Anotación) J Manda de Tereysa de Meira.

1475, enero, 8.- Pontevedra.

Testamento de Gregorio de Valladares, regidor de Pontevedra, hijo de Gonzalo de Valladares, por el que nombra como heredero a su hijo Pedro Vázquez de Valladares y a la hermana de este, Teresa de Meira.

LA CORUÑA, ARG, Colección Sarmiento Valladares, 44976, Caja 168, núm. 4, papel, copia simple, gallego, letra gótica redonda con algunos rasgos de cortesana en los últimos folios, se transcribe esta; le acompañan otras dos copias simples de época moderna y contemporánea; 44976, Caja 168, núm. 6, papel, traslado notarial de Gonzalo de Reguera, escribano del rey y del cabildo de Santiago, a pedimento del canónigo Diego Suárez de Tangil, para la Real Audiencia y Chancillería de Valladolid en 24 de octubre de 1576, gallego, letra humanística.

PONTEVEDRA, Museo de Pontevedra, Col. Sampedro, C. 81-1, núm. 14, papel, copia simple.

Catálogo: María Miramontes Castro, "Catálogo da documentación medieval do Museo de Pontevedra”, El Museo de Pontevedra, 50 (1996), doc. núm. 967, pág. 340.

Cita Eduardo Pardo de Guevara y VAldés, De linajes, parentelas y grupos de poder. Aportaciones a la historia social de la nobleza bajomedieval gallega, Madrid, Fundación Cultural de la Nobleza Española; CSIC, 2012, págs. 96-97.

En o nome de Deus, amen. Ano do nasçemento de noso I Senor Ihesu Christo de mill et quatroçentos et setenta et I çinco anos, oyto dias do mes de janeyro. 
Sabean todos I que eu, Gregorio de Valadares, regidor da vila de Pontelvedra, que soo presente, seendo sao et con saude I et con todo meu syso et entendemento conplido qual me Deus I deu, et temendo a morte porque ey de pasar et non sey quando ni como, I por ende faço mina manda et testamento, et hordeno de meus bens colmo despoys de mina morte mays beens et fazenda fiquen hordenadalmente a serviçio de Deus et a prol et saud de mina alma; primelyramente mando a mina alma a o meu sennor Ihesu Christo, que a conprou I et redemeu por lo seu santo sangre, justo, preçioso, et rogo et pido I de merçede a a bendita Virgen Santa Maria, sua madre, con toda a corte I çelestial, que seja mina avogada a a o[ra da] mina morte et a [o] I dia do grand juyso, et quando a Deus aprouver de me levar I desta presente vida, mando meu corpo seer sepultado en o I moesteyro de Santo Domingo da dita villa de Pontevedra, onde jaz I meu padre Gonçalo de Valadares, que Deus aja. $\int$ Yten mando que I me digan dez misas cantadas et sasenta resadas aquel dia $I$ et anos outros siguintes por mina alma et de aqueles que soo I theudo. $\int$ Iten mando que me digan vinte salteyros. $\int$ Yten malndo a o lume et obra de Santa Maria a Grand<e> quynientos maravedis, et outros I quinientos por disimos, de que entendo que lle soo theudo. S Iten malndo a yglesia de San Bertolameu, por disimos de que entendo que lle soo I theudo, seysçentos maravedis vellos, et outros seysçentos para o I lume et obra. $\int$ Iten mando a o moeste-

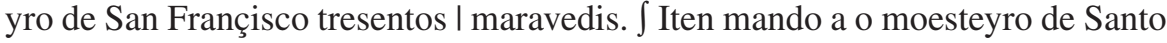
Domingo, por honrra II de mina sepultura, dous mill pares de blancas et que me honlrren segund que pertençe a mi. S Iten mando que os mosteyros de San Iohan I de Poyo, Leres, Armenteyra, Tanoyro et San Françisco et as yglesias de I San Bertolameu et Santa Maria a Grand<e que > me van honrrar et dizer suas misas I et honrras, segund que me pertesçe, et lles de mays a metad de quanto se alcustuma de se lles dar por qualquer home honrado. $\int$ Iten mando a Santa I Maria de Vigo, onde jas mina madre, mill pares de blancas. $\int$ Iten mando I a San Romao de Sajamond $<$ e $>$ que lles den un calis de prata que pese un marlco. $\int$ Iten mando a lo mosteyro/ <de $>$ San Domingo de Tuy mill pares de blancas, I et mandolle Imays/ en cada un ano que lle den por dia de Todos Santos hun I par de carneyros, a metad de a vaca et dous odres de vino, un de blanco et outro I de tinto, et seys çelemiins de trigo cosido en pan, et que roguen a Deus I por mi. $\int$ Iten mando a o mosteyro de Sant Domingo de Pontevedra oultro tanto en cada un ano para senpre, et outro tanto a Santa Maria de Vigo. I Iten mando a Santa Vaya de Meyra tresentos maravedis para o lume et obra. I Yten mando a Santa Clara de Pontevedra tresentos marevedis et outros I tresentos a Santa Maria do Camino para pan, et mays mando a dita I hermida dozentos maravedis para ajuda de un cales ou de una lanpaa. $\int$ Iten I mando que se paguen todos los males et dapnos que eu fize fasta oje, I os que se poderen pagar et os que se non poderen pagar, todos que les paguen I delo et lles peçan perdon por lo mays. S Iten mando que a 
o tenpo de minas I honrras quebren por mi una duzea d'escudos et arrastren meus penldons pintados das armas de Meyra et Valadares et Canba, et den a meus I criados et amos et amas, a cada un, sua capa de loyto. S Iten mando I a mina moller toda a renta de meu benefiçio de San Christobo, que he en $<$ te $>$ rra I de Canba, para que o aja et leve en sua vida, et rogo et pido a meus yrmaos I me leixe $<$ n $>$ aquelo a mina parte para que o ela aja et leve en toda sua vida, I et a seu saymiento dela, mando que o aja et leve Ares de Canva, meu fillo I bastardo que ouve de Joana, et se morrer menor de ydade, que quede a meus $\|$ herdeyros. $\int$ Iten mando a Catalina Lourença, a Moça, çinco mill palres de blancas para ajuda de seu casamiento, et mays una aljuva de aquel I pano pardillo que ten sua madre. $\int$ Iten mando que façan outra aljuba \a sua madre/ I de aquel mismo pano. J Iten mando a meu criado Pedro Pedreyro unas calças I de sobredito pano et a mina capa enforrada con seda que he daquel I mismo pano. S Iten lle mando mays a el et a sua moller o pan que rende I Santo Andre de Valadares en quanto mais meus fillos foren menores de ydade, I et rogolle et pido que miren por eles asi como eu miraria por el si lle I conprira. $\int$ Iten mando a Ruy Gomes ogi ( $\mathrm{sic}$ ) vinte et quatro quartos de trigo et I çenteo que ha de dar Pedro Costas, et que o aja et leve en toda sua vida. $\int$ Iten I lle mando mays que o vistan de pano pardo. $\int$ Iten mando mays a Maria I Alvares de Vigo a mina alcavala de Valadares et o trigo et çenteo I que pagan por la herdade de Prado, que so $<\mathrm{n}>$ des et seys quartos, o qual I todo lle mando en sua vida. $\int$ Iten mando a Afonso de Colinas que sirlva os ditos meus fillos asy como servia a min, et que lle I leyxo aquel lugar en que el vibe forro ${ }^{93}$ et quite en sua vida. $\int$ Iten I mando a Gonzalo de Meyra que lle leyxo o lugar de Iohan Manso con suas I herdades libre et quitas, en sua vida, sen por el pagar cousa alguna. I I Iten mando a meu amo Pedro Garçia et a Juan Polveyro et a Juan do Espino I que lles paguen todo o que eles diseren et que mina madre lle eramos encargo, et mays mando a o dito meu amo et colaço Juan Polveyro qual les leixo I as herdades et cousas que labren minas, forras et quitas, en suas vidas. I I Iten mando que a todos meus vasalos por alguas cousas que lles levey I et pide (sic), que llas leyxo, depoys de mina manda conplida, as avinças I et serviços fasta que meus fillos sejan de hedade. J Iten mando I que partan as cousas propias con meus yrmaoos segundo que as partiron Pedro I Albares de Valadares et Vasco Fernandes de Valadares, et das outras cousas II que a meu cabo perteesçe faço meus herdeyros a Pedro Vaasques de Valadares, I meu fillo, et a? Teresa ${ }^{94}$ de Meyra, sua yrmaan, et asimismo de toldos los outros meus beens mobles et rayzes que eu teno, minas I mandas conplidas, os quaes beens mando que ajan et herden en esta guisa: I que por quanto a o dito Pedro Vasques, meu fillo, per-

\footnotetext{
${ }^{93}$ Horro, libre, exento, desembarazado.

${ }^{94}$ Parece que dejaron el espacio en blanco por duda, y posteriormente lo que se escribió es de difícil interpretación.
} 
teesçe o mioradigo ( $\mathrm{sic}$ ), mando I que leixe a dita sua yrmaa o couto de Meyra et a mayor parte dos I casares propios que me acaesçeren dos casares de Canba et Pias et Moulriscasdos et Salvaterra, et as colleytas dos benefiçios que a min perteesçen I en Torono, salvo das freiguesias que a el perteesçen, que son estas, os feuldos da yglesia de Santiago. J Iten lle mando mays que aja et herde a I casa de Valadares, a melloro en o meu couto de Sajamonde con suas I vinas, casas et herdades et con todas suas perteenças para que ninguna I non posa partir con el. Et faço sustituyçion pupilar ${ }^{95}$ que morrendose I cada un deles sen seme et menores de ydade, que se tornen a o outro, I asi de un en outro, et faleçendose anbos menores que se tornen I [...] meus beens a quen os de dereyto ouver de herdar. Et leixo por titores dos I ditos meus fillos a Lopo [Ta]boado et a Juan Rodrigues Moula. Et faço conplidores I desta dita mina manda et testamento <para $>$ que a conplan et paguen por meus beens et sen seu dapno a o mestre Migel de Vilaboa, I flaire de San Domingo, et a frey Afonso de Lima, bachiller, et a Gonçalo I Esteyro, escripvano, para que a cunplam et collan todas minas rentas I fasta ela ser conplida; et mando a cada un para seu traballo dous I mill pares de blancas. Et couto esta dita mina manda en duas mill I dobras d'ouro, que quero et outorgo que peite et paguen de pena qualquer persona I da mina parte ou da estrana que contra ela for ou pasar para o quebrantar, I en parte ou en todo. Et revoco et dou por ninguas todas et quaesquer outras I mandas et condeçillos que fasta oje este dito dia tenan (tachado) feitas et outorgadas, II en qualquer maneyra et por qualquer rason, que quero et outorgo que non valla nen faça I fe en juyzio nen fora del, salvo esta que oje este dito dia faço et outorgo en preselnçia deste notario et ts $^{\mathrm{o}}$. de juso escriptos; et a aparto todos los outros meus parentes I et parentas con çinco soldos de boa moeda, que quero et outorgo que non aja nen herden I mays de meus beens. Et a pena pagada ou non, esta dita mina manda et as en ela I conteudas fiquen firmes et vallan en sua rebor. Et leixo por exsecutor de mina malnda, para que façan cunplir et tenan cargo de meus fillos et do seu en quanto foren menolres, et despois os aja $<\mathrm{n}>$ para si, a o viscond $<\mathrm{e}>$ de Finsterra, meu sennor.

Feita et outorgalda en Pontevedra, ano, dia, mes susoditos.

$\mathrm{Ts}^{\mathrm{o}}$. que foron presentes: Gonçalo Esteyro, I et Afonso Ares, canbeador de Santiago, et Afonso Barbeyro, et Johan de Santiago, carpenteyro, et Rui da Aç $[o$ ? ]renra.

Valadares, regidor.

\footnotetext{
${ }_{95}$ Nombramiento de sucesor en los bienes del pupilo que por no haber llegado a la edad de la pubertad no puede hacer testamento.
} 
Et eu, Françisco Fernandes, escrivano de camara del rey, nuestro senor, et seu notario publico en a I sua corte et en todos los seus reinos et senorios, et notario publico da I çibdade de Pontevedra et do moesteyro de San [Iohan de Poyo et coutos et lugares] I del por [lo] senor arçobispo et iglesia de Santiago, a o outorgamiento da so[bre] I dita manda segund que de arriba dito he, en un con os ditos testigos ( sic), presente I fuy et a fise escrevir en estas duas follas de papel con esta en que vai I meu signo et subes [...] Lionor de Meira, hermaan (sic) do dito Grilgorio de Baladares, que [...] sten dita de aproveitar dela, a qual lle dey I por mandamiento que me [...] so Lopo de Montenegro, juis hordenario I da vila de Pontevedra [...] da dita Lionor de Meira, et por ende I fise escrevir et aqui [este dito meu no]me et signo puge en testemonio I de verdade.

\section{BIBLIOGRAFÍA}

Álvarez Borge, Ignacio, Poder y relaciones sociales en Castilla en la Edad Media: los territorios entre el Arlanzón y el Duero en los siglos X al XIV, [Valladolid], Junta de Castilla y León, Consejería de Educación y Cultura, 1996 (Col. Estudios de historia, Castilla y León. Consejería de Educación y Cultura).

Andrade Cernadas, José Miguel, Lo imaginario de la muerte en Galicia en los siglos IX al XI, Sada, Ediciós do Castro, 1992.

Andrade Cernadas, José Miguel, "Los testamentos como reflejo de los cambios de actitud ante la muerte en la Galicia del siglo XIV”, Semata, 17 (2005), págs. 97-114.

Andrade Cernadas, José Miguel, "La violencia recordada. Confesiones testamentarias en la Galicia de finales de la Edad Media”, Semata, 19 (2007), págs. 65-77.

Antonio Rubio, María Gloria de, "Onomástica y uso del «Don» entre los judíos gallegos medievales", Estudios de genealogía, heráldica y nobiliaria de Galicia, 3 (2004), págs. 433-452.

Aponte, Vasco de, Recuento de las casas antiguas del Reino de Galicia, Introducción y edición crítica a cargo del Equipo de Investigación "Galicia hasta el 1500" integrado por Manuel Díaz y Díaz et al., Santiago de Compostela, Consellería da Presidencia, Servicio Central de Publicacións, 1986.

Aragón en la Edad Media: la prosopografía como método de investigación sobre la Edad Media: sesiones de trabajo, Zaragoza, Universidad de Zaragoza, Departamento de Historia Medieval, Ciencias y Técnicas Historiográficas, 2006.

Ariès, Philippe, La muerte en Occidente, Barcelona, Argos-Vergara, 1982.

Azpeitia Martín, María, "Historiografía de la 'Historia de la Muerte'”, Studia Historica. Historia Medieval, 26 (2008), págs. 113-132.

Beceiro Pita, Isabel, "Modas estéticas y relaciones exteriores: la difusión de los mitos artúricos en la Corona de Castilla (s. XIII - comienzos s. XVI)", En la España medieval, 16 (1993), págs. 135-168.

Beceiro Pita, Isabel, "La aristocracia de Castilla y sus abogados celestiales", Estudios de Historia de España, 12 (2010), págs. 27-48. 
Beceiro Pita, Isabel y Córdoba de la Llave, Ricardo, Parentesco, poder y mentalidad. La nobleza castellana. Siglos XII-XV, Madrid, Consejo Superior de Investigaciones Científicas, 1990.

Bejarano Rubio, Amparo, El hombre y la muerte: los testamentos murcianos bajomedievales, Cartajena, Ayuntamiento de Cartajena, 1988.

Brolis, Maria Teresa y Zonca, Andrea, Testamenti di donne a Bergamo nel medioevo, Bergamo, Fondazione Mia, 2012.

Calderón, Carlos, "Mujeres, ideología y cotidianeidad en la Galicia de mediados del siglo XVI. Un estudio de caso: el testamento e inventario de bienes de la condesa de Altamira, doña Ana de Toledo", Revista de Historia, 3 (1992), págs. 107-128.

Calderón, Carlos, "Testamentos, codicilos y escrituras públicas. Evolución de las formas y contenidos de la última voluntad femenina en Galicia (siglos XII-XV)", Minius, 15 (2007), págs. 7-32.

Calderón, Carlos, "Cambios y persistencias en la mentalidad nobiliaria gallega en el tránsito de la Edad Media a la Moderna según la literatura testamentaria. Un estudio comparativo", Cuadernos de Estudios Gallegos, 54, núm. 120 (2007), págs. 171-188.

Calderón, Carlos, "Doña Urraca de Moscoso: de la crónica a su testamento. Perfil de una noble gallega de la segunda mitad del siglo XV", La Aljaba, segunda época. Revista de Estudios de la Mujer, 11 (2007), págs. 211-228.

Calderón, Carlos, "Algunas notas sobre el patrimonio de la boticaria Elvira Pérez (Santiago, 1348)", Estudios de Historia de España, X (2008), págs. 125-135.

Calderón Medina, Inés, Cum magnatibus regni mei. La nobleza y la monarquía leonesas durante los reinados de Fernando II y Alfonso IX (1157-1230), Madrid, Consejo Superior de Investigaciones Científicas, 2011 (Biblioteca de Historia, 74).

Campo Gutiérrez, Ana del, El Libro de Testamentos de 1384-1407 del notario Vicente de Rodilla. Una introducción a los documentos medievales de últimas voluntades de Zaragoza, Zaragoza, Institución "Fernando el Católico", 2011.

Carlé, María del Carmen, Una sociedad del siglo XV. Los castellanos en sus testamentos, Buenos Aires, Universidad Católica Argentina, 1993.

Casamitjana i Vilaseca, Jaume, El testamento en la Barcelona bajomedieval. La superación de la muerte patrimonial, social y espiritual, Pamplona, Universidad de Navarra, 2004.

Castro Pérez, Felipe, A Casa de Valladares: formación e evolución do patrimonio dunha familia dominante na Pontevedra do Antigo Réxime, [Pontevedra], Deputación Provincial de Pontevedra, Servizo de Publicacións, 2004.

Cendón Fernández, Marta, "La imagen de la mujer en el arte bajomedieval gallego", en Miguel García-Fernández, Silvia Cernadas Martínez y Aurora Ballesteros Fernández (eds.), As mulleres na historia de Galicia. Actas do I Encontro Interdisciplinar de Historia de Xénero, Santiago de Compostela, Andavira, 2012, págs. 81-100.

Cendón Fernández, Marta, Fraga Sampedro, M. ${ }^{a}$ Dolores y Barral Rivadulla, M. ${ }^{a}$ Dolores, Arte y poder en la Galicia de los Trastámara: la provincia de La Coruña, Santiago de Compostela, Tórculo, 2000. 
Chiffoleau, Jacques, La comptabilité de l'au-delà. Les hommes, la mort et la religion dans la région d'Avignon à la fin du Moyen Âge (vers 1320 - vers 1480), Roma, École Française de Roma, 1980.

Colección de documentos históricos del Boletín de la Real Academia Gallega, La Coruña, Real Academia Gallega, 1915, vol. I.

Colección Diplomática de Galicia Histórica, Santiago de Compostela, Tipografía Galaica, 1901.

Comas Via, Mireia, Les dones soles a la Baixa Edat Mitjana: una lectura sobre la viduïtat, tesis doctoral inédita, Barcelona, Universitat de Barcelona, 2012.

Coria Colino, Jesús, "El testamento como fuente de estudios sobre mentalidades (s. XIII al XV)", Miscelánea Medieval Murciana, IX (1982), págs. 193-222.

Ferro Couselo, Xesús, A vida e a fala dos devanceiros. Escolma de documentos en galego dos séculos XIII ao XVI, Vigo, Galaxia y Fundación Penzol, 1967, 2 vols.

Fernández Suárez, Gonzalo Francisco, La nobleza gallega entre los siglos XIV-XV. Los Sarmiento Condes de Ribadavia, Santiago de Compostela, El Eco Franciscano, 2002.

Framiñán Santas, Ana María, "O título vizcondal de Fisterra no contexto da creación de títulos en Galiza na Idade Media", Boletín de Estudios de Genealogía, Heráldica y Nobiliaria de Galicia, 3 (2004), págs. 421-431.

Framiñán Santas, Ana María y Presedo Garazo, Antonio, "Estructuras de parentesco de la nobleza gallega en 1350-1600: una primera valoración", Obradoiro de Historia Moderna, 14 (2005), págs. 109-140.

García-Fernández, Miguel, "Las Sarmiento: mujeres con poder al final de la Edad Media", en M. ${ }^{a}$ Isabel del Val Valdivieso y Cristina Segura Graiño (coords.), La participación de las mujeres en lo político. Mediación, representación y toma de decisiones, Madrid, A. C. Almudayna, 2011.

García-Fernández, Miguel, As mulleres nos testamentos galegos da Idade Media, tesis de licenciatura inédita, Santiago de Compostela, Universidade de Santiago de Compostela, 2012.

García-Fernández, Miguel, "Doña Beatriz de Castro: una mujer con nombre propio en el siglo XV ourensano", en Clara Elena Prieto Entrialgo (ed.), El mundo urbano en la España cristiana y musulmana medieval, Oviedo, Asturiensis Regni Territorium, 2013, págs. 159-174.

García-Gallo, Alfonso, "Del testamento romano al medieval. Las líneas de su evolución en España”, Anuario de Historia del Derecho Español, XLVII (1977), págs. 425-497.

García González-Ledo, Xosé Antón, “Testamentos do mariscal Álvaro González de Ribadeneira e a súa muller María de Bolaño (século XVI)”, Estudios Mindonienses, 23 (2007), págs. 845-873.

García Oro, José, La nobleza gallega en la Baja Edad Media. Las casas nobles y sus relaciones estamentales, Santiago de Compostela, Bibliófilos Gallegos, 1981 (Biblioteca de Galicia, 20).

García Oro, José y Portela Silva, María José, La Casa de Altamira durante el Renacimiento. Estudio introductorio y colección diplomática, Santiago de Compostela, El Eco Franciscano, 2003. 
García Tato, Isidro y Álvarez Álvarez, Eleutino, Las encomiendas gallegas de la Orden Militar de San Juan de Jerusalén. Estudio y edición documental. La encomienda de Quiroga, tomo 2-1, Santiago de Compostela, CSIC-Xunta de Galicia, 2010.

García Tato, Isidro y Otero Piñeyro Maseda, Pablo S., "Asentamiento, desarrollo y ocaso de la Orden del Santo Sepulcro en Galicia. Un panorama general y un documento singular", Cuadernos de Estudios Gallegos, 59, núm. 125 (2012), págs. 65-94.

Gerbet, Marie-Claude, Las noblezas españolas en la Edad Media: siglos XI-XV, Madrid, Alianza, 1997 (Alianza universidad, 871).

Gómez Cid, Graciela, "A morte feminina no Ourense baixomedieval”, Diversarum rerum, 4 (2009), págs. 227-241.

González Fernández, Juan Miguel, "Genealogía de la Casa de Valladares (hasta el siglo XVII)", Boletín do Instituto de Estudios Vigueses (Glaucopis), 13 (2007), págs. 59-76.

González Lopo, Domingo Luis, Los comportamientos religiosos en la Galicia del Barroco, Santiago de Compostela, Xunta de Galicia, 2002.

Jimenez Gómez, Santiago, "O «Memorial de Aniversarios» da Catedral de Lugo como fonte para o estudio da sociedade medieval", en Jubilatio: homenaje de la Facultad de Geografía e Historia a los profesores D. Manuel Lucas Alvarez y D. Angel Rodríguez González, Santiago, Universidade, Servicio de Publicacións e Intercambio Científico, 1987, vol. 1, págs. 161-227.

Manso Porto, Carmen, "El códice medieval del convento de Santo Domingo de Santiago (II)", Archivo Dominicano, IV (1983), págs. 75-129.

Manso Porto, Carmen, Arte gótico en Galicia. Los dominicos, A Coruña, Fundación Pedro Barrié de la Maza, 1993, 2 vols.

Martín Cea, Juan Carlos, "El modelo testamentario bajomedieval castellano y su reflejo en los diferentes grupos sociales", Edad Media. Revista de Historia, 6 (2003-2004), págs. 103-156.

Ministerio De Cultura, Portal de Archivos Españoles (PARES) [en línea], disponible en < http://pares.mcu.es/ >.

Miramontes Castro, María, "Catálogo da documentación medieval do Museo de Pontevedra", El Museo de Pontevedra, 50 (1996), págs. 109-432.

Morujão, Maria do Rosário Barbosa (coord.), Testamenti Ecclesiae Portugaliae (1071-1325), Lisboa, Centro de Estudos de História Religiosa y Universidade Católica Portuguesa, 2010.

Normas de transcripción y edición de textos y documentos, Madrid, Escuela de Estudios Medievales, CSIC, 1944.

Núñez Rodríguez, Manuel, La idea de inmortalidad en la escultura gallega. La imaginería funeraria del caballero, ss. XIV-XV, Ourense, Deputación Provincial de Ourense, 1985.

Otero Piñeyro Maseda, Pablo S., Colección documental del Archivo de la Casa de Otero de Quiroga (siglos XIII-XVIII), Lugo, Publicaciones de la Diputación Provincial de Lugo, 2007 (Col. Historia).

Otero Piñeyro Maseda, Pablo S., "O apoxeo dos escudeiros na Galiza baixomedieval. O caso dos Vilariño. O seu patrimonio e parentelas", História. Revista da Faculdade de Letras, 10 (2009), págs. 129-144. 
Pallares Méndez, María del Carmen, "El sentimiento de la muerte y su influencia en la sociedad gallega bajomedieval", en Xavier Castro e Jesús de Juana (eds.), Mentalidades colectivas e ideoloxías. VI Xornadas da Historia de Galicia, Ourense, Deputación Provincial de Ourense, 1991, págs. 211-227.

Pallares Méndez, María del Carmen y Portela Silva, Ermelindo, "Los mozos nobles: grandes hombres, si fueran hijos solos”, Revista d'Història Medieval, 5 (1995), págs. 55-74.

Pardo de Guevara y Valdés, Eduardo, “¿Hacia una nueva ciencia genealógica? Reflexiones para una renovación en sus métodos y objetivos”, Medievalismo, 2 (1992), págs. 171-183.

Pardo de Guevara y Valdés, Eduardo, Los señores de Galicia. Tenentes y condes de Lemos en la Edad Media, A Coruña, Fundación Pedro Barrié de la Maza, 2000, 2 vols.

Pardo de Guevara y Valdés, Eduardo, De linajes, parentelas y grupos de poder. Aportaciones a la historia social de la nobleza bajomedieval gallega, Madrid, Fundación Cultural de la Nobleza Española; CSIC, 2012.

Pardo Villar, P. Aureliano, OP, "El convento de Santo Domingo de Ribadavia", Boletín de la Comisión Provincial de Monumentos Históricos y Artísticos de Orense, 9, núm. 206 (septiembre-octubre 1932), págs. 409-416.

Paredes Mirás, María del Pilar, Mentalidade nobiliaria e nobreza galega. Ideal e realidade na Baixa Idade Media, Noia, Toxosoutos, 2002.

Pavón Benito, Julia y García de la Borbolla, Ángeles, Morir en la Edad Media. La muerte en la Navarra medieval, Valencia, Universitat de València, 2007.

Pérez Rodríguez, Francisco Javier, "Diferencias sociales más allá de la muerte. El recuerdo de los difuntos en la Galicia medieval (siglos XII-XV)", en ¿Quen manda aquí? O poder na historia de Galicia. VII Semana Galega de Historia, Santiago de Compostela, Asociación Galega de Historiadores, 1999, págs. 127-142.

Pizarro, José Augusto de Sotto Mayor, Linhagens Medievais Portuguesas. Genealogias e Estratégias (1279-1325), Porto, Universidade Moderna; Centro de Estudos de Genealogia, Heráldica e História da Família, 1999, 2 vols.

Portela Silva, La región del obispado de Tuy en los siglos XII a XV. Una sociedad en la expansión y en la crisis, Santiago de Compostela, El Eco Franciscano, 1976.

Portela Silva, Ermelindo y Pallares Méndez, María del Carmen, "Muerte y sociedad en la Galicia medieval (siglos XII-XIV)", en Manuel Núñez Rodríguez y Ermelindo Portela Silva (coords.), La idea y el sentimiento de la muerte en la historia y en el arte de la Edad Media, Santiago de Compostela, Universidade de Santiago de Compostela, 1988, págs. 21-29.

Portela Silva, Ermelindo y Pallares Méndez, María del Carmen, De Galicia en la Edad Media. Sociedad, espacio y poder, Santiago de Compostela, Xunta de Galicia, 1993.

Portela Silva, María José y García Oro, José, La iglesia y la ciudad de Lugo en la Baja Edad Media: los señoríos, las instituciones, los hombres, Santiago de Compostela, Instituto Padre Sarmiento de Estudios Gallegos, 1997 (Anejo 24 de Cuadernos de Estudios Gallegos).

Presedo Garazo, Antonio, "Los logros materiales y simbólicos de una mujer noble en Galicia a comienzos de la época moderna: Doña Violante de Andrade (c. 1484-1538), Semata, 20 (2008), págs. 189-218. 
LOS TESTAMENTOS COMO FUENTE PARA LA HISTORIA SOCIAL DE LA NOBLEZA. UN EJEMPLO METODOLÓGICO: TRES MANDAS DE LOS VALLADARES DEL SIGLO XV

Ríos Rodríguez, María Luz, "Aproximación a los testamentos de la Catedral auriense (ss. XIIXIII): disposiciones terrenales y espirituales", Semata, 17 (2005), págs. 75-96.

Rodríguez Estevan, María Luz, Testamentos medievales aragoneses. Ritos y actitudes ante la muerte (siglo XV), Zaragoza, Ediciones 94, 2002.

Romaní Martínez, Miguel, "El monasterio cisterciense de Santa María de Melón. Observaciones sobre los Tumbos 323, 324 y 325 del Archivo Histórico Nacional. Los testamentos de don Giraldo y de Alonso Yanes Churruchao", Boletín Auriense, 41-42, (No lembrar Olga Gallego Domínguez), vol. 1 (2011-2012), págs. 263-276.

Royer de Cardinal, Susana, Morir en España: Castilla Baja Edad Media, Buenos Aires, Universidad Católica de Argentina, s.f.

Salazar y Acha, Jaime de, Génesis y evolución histórica del apellido en España: discurso leído el día 26 de mayo de 1991 en el acto de su recepción pública..., Madrid, Real Academia Matritense de Heráldica y Genealogía, 1991.

Sánchez Ameijeiras, Rocío, "Actitudes ante la muerte en las mujeres de la nueva nobleza enriqueña: la escultura funeraria como fuente para la historia de las mentalidades", en Ángela Muñoz Fernández (ed.), Las mujeres en el cristianismo medieval. Imágenes teóricas y cauces de actuación religiosa, Madrid, Almudayna, 1989, págs. 451-461.

Sánchez Ameijeiras, Rocío, "El arnés y el armamento del caballero medieval gallego (13501450)", Acta histórica et archaeologica mediaevalia, 10 (1989), págs. 427-436.

Sánchez Sesa, Rafael, "Modelos de muerte y mentalidad religiosa en la península ibérica. Los testamentos entre las élites castellanas de la segunda mitad del siglo XIV a la segunda del XV”, Ilu. Revista de Ciencias de las Religiones, 5 (2000), págs. 163-178.

Taylor, Nathaniel Lane, The will and society in Medieval Catalonia and Languedoc, 8001200, Cambridge, Harvad University, 1995.

Tollerton, Linda, Wills and will-making in Anglo-Saxon, Rochester; Nueva York, York Medieval Press; Boydell Press, 2011.

Vilar, Herminia Vasconcelos, A vivência da morte no Portugal medieval: a Estremadura portuguesa (1300 a 1500), Redondo, Patrimonia, 1995.

Vivanco, Laura, Death in fifteenth century Castile. Ideologies of the elites, Suffolk, Rochester, Nueva York, Tamesis, 2004. 